\title{
THE HUMAN EMBRYONIC HEART IN THE NINTH WEEK
}

\author{
RICHARD H. LICATA \\ Department of Anatomy, University of Michigan Medical School, Ann Arbor ${ }^{1}$ \\ SIXTEEN FTGURES
}

Although observations on the developing heart go back to the time of Aristotle, it was not until late in the 19 th century that the work of His (1885, 1886) and Born (1888, 1889) resulted in an understanding of heart development that was of sufficient accuracy to be still of basic value by present standards. One of the crucial factors in their work was the development of adequate methods of reconstruction. Although His was the first to attempt such reconstructions, his efforts met with limited success and he had to resort to freehand modelling of embryonic hearts. These models, reproduced commercially by Ziegler, are fairly accurate, though they lack the detail of models made by the wax-plate method. In 1883 Born began to employ the wax-plate reconstruction method as a means of studying heart development. This technique was improved by Kastschenko (1886) and Strasser (1887). Later, the continued efforts of Born and Strasser brought this technique to a high degree of accuracy. A description of their methods was published in detail by Born in 1889 .

Tandler ('12, '13) greatly furthered knowledge of heart development by coördinating the results of earlier workers and supplementing them with extensive contributions of his own. Mall's work ('12) on the structure of the ventricles, and his observations on the development of the conduction sys-

${ }^{1}$ This paper represents a condensation of one section of a dissertation submitted in partial fulfillment of the requirements for the degree of Doctor of Philosophy in the University of Michigan. 
tem, appeared concurrently. Davis ('25, '27) provided a comprehensive account of some of the early phases of cardiogenesis. Knowledge of the valves, especially those of the sinus venosus, was augmented by Chiari (1897) and Rokitansky (1875). The importance of the highly variable vestiges of these valves in the adult was emphasized by Yater ('29) and later by Wright, Anson and Cleveland ('48).

Recently emphasis has been placed on the interatrial septal complex and the functional significance of its valvular mechanism. The extensive work of Patten ('30, '31, '38, '53), Barclay and his co-workers ('44), Barcroft ('47), and Franklin ('48) has contributed to understanding of the intracardiac balance in the prenatal circulation. These papers will be discussed in connection with the findings here presented concerning the formation of the interatrial septal complex.

Although present knowledge of heart development is extensive there are many phases which require re-examination. The present study was undertaken to ascertain the state of development of certain rapidly changing structures at relatively advanced stages which, as yet, have not been studied in detail. The selection of embryos in the 9th week was dictated also by the fact that most of the major cardiac structures are clearly established at this age, but are nevertheless still sufficiently embryonic to reflect the developmental processes involved in their origin.

In selecting this period for special study due cognizance was taken of the fact that previous investigators, namely, Born (1889), Waterston ('18), and Tandler ('12), have included hearts at approximately this stage of development in their series of reconstructions. Although their studies provide excellent foundational data in regard to the heart at this age, they do not deal with many details that have assumed increasing importance as knowledge of the general pattern of cardiac development has advanced. There is, for example, very little in these earlier papers on the histogenesis of the heart, a subject to which this study gives special attention. Moreover, in recognition of the fact that many of the mor- 
phogenetic changes are intimately correlated with prevailing functional activities, the dynamic aspects of heart development, wherever possible, have been taken into consideration.

\section{MATERTALS AND METHODS}

The University of Michigan embryological collection of serial sections of human embryos provided the material chiefly used in this work. Many of these specimens had come in without detailed clinical histories and the ages here given were estimated on the basis of the table and graphs in Patten's Human Embryology ('46). His age-length curves fall in the zone between the earlier ones of Mall ('18) and the more recent ones of Streeter ('51). Although embryos within the 9th week of development were selected for intensive study, younger and older specimens were examined to determine the course of cardiac development in the adjacent age ranges. The two most promising embryos were EH 164, $25 \mathrm{~mm}$ C-R (Streeter's Horizon XXII), and EH 377, 31.5 mm C-R (Streeter's Horizon XXIII). Both of these embryos had been cut in a transverse plane at $10 \mu$. Wax-plate reconstructions $(\times 100)$ were made of the hearts of these two embryos. Wax of different colors was employed to distinguish such structures as cardiac vessels, conduction tissue, nerves, endocardial cushion tissue, and epicardial connective tissue. In addition, transparent reconstructions were made from sheets of plastic material on which the various structures had been drawn in color. This latter method was used for restricted regions such as the septum membranaceum, parts of the conduction system, and the dorsal aspect of the heart to show its relation to the posterior mediastinum and its contents, especially the nerves. These reconstructions, coupled with dissections under a wide-field binocular and histological study of sections, further supplemented by the collateral study of a number of additional hearts falling within the same and adjacent age groups, yielded a comprehensive picture of the heart in the 9 th week. 
With the exception of a limited number of slides within one series which had been stained with Masson and Heidenhain's Azan triple stains, both embryos selected for reconstruction had been prepared with haematoxylin and eosin. As a result some of the histological differentiations were more difficult to make than would have been the case had special staining techniques been more extensively employed.

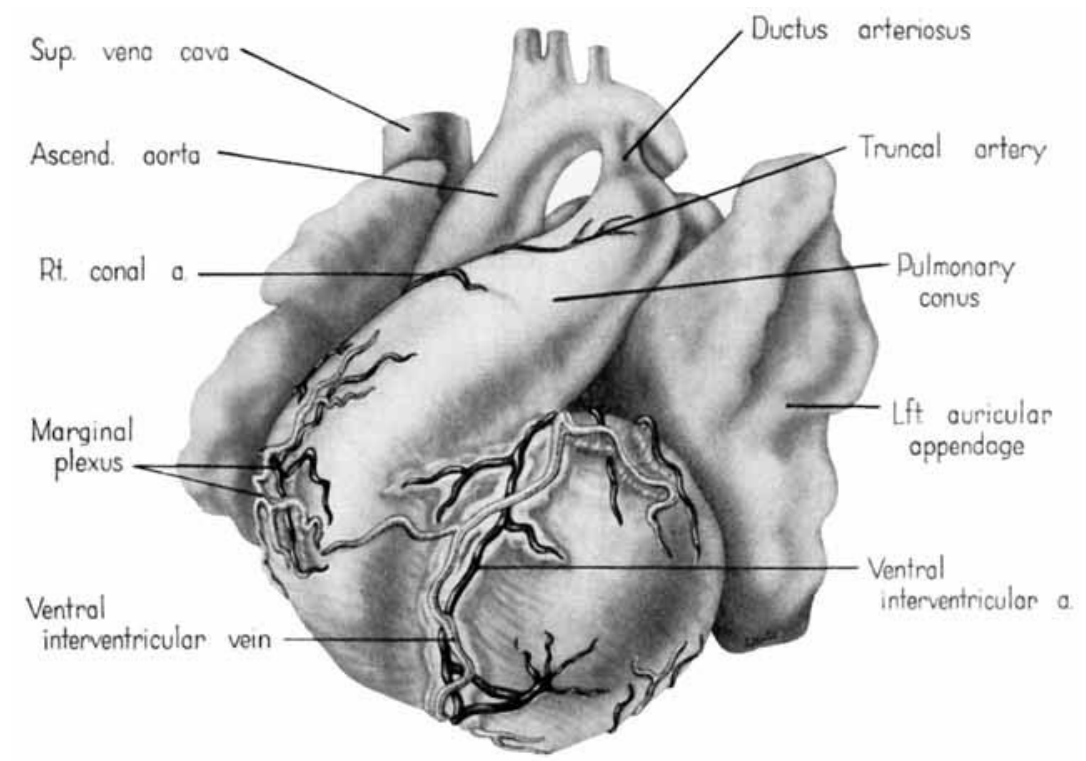

Fig. 1 Ventrocephalic aspect of heart of $31.5-\mathrm{mm}$ embryo showng the superficial cardiac vessels. The arch of the aorta has been represented as if pulled craniat a little, to show the ductus arteriosus more clearly. (Reconstruction $\times 100$, illustration $\times 34$.)

In spite of this, the differentiation of the conduction system, and some of the elements of the associated nervous tissues, had progressed sufficiently to make their identification possible.

\section{OBSERVATIONS}

General orientation and external configuration

$$
\text { of heart }
$$

In embryos of the 9th week the heart has assumed an orientation within the thoracic eage such that its apex lies opposite 
the 5th intercostal space. The apical end of the heart is, however, more strongly directed to the left than is that of the adult.

The external configuration of the heart is at this stage essentially similar to that of the postnatal heart (figs. 1, 2). The truncus arteriosus has completed its division into ascending aorta and pulmonary trunk. In the territory of the great veins the two splanchnic layers of the primary dorsal mesocardium early became backed by a mass of loose embryonic

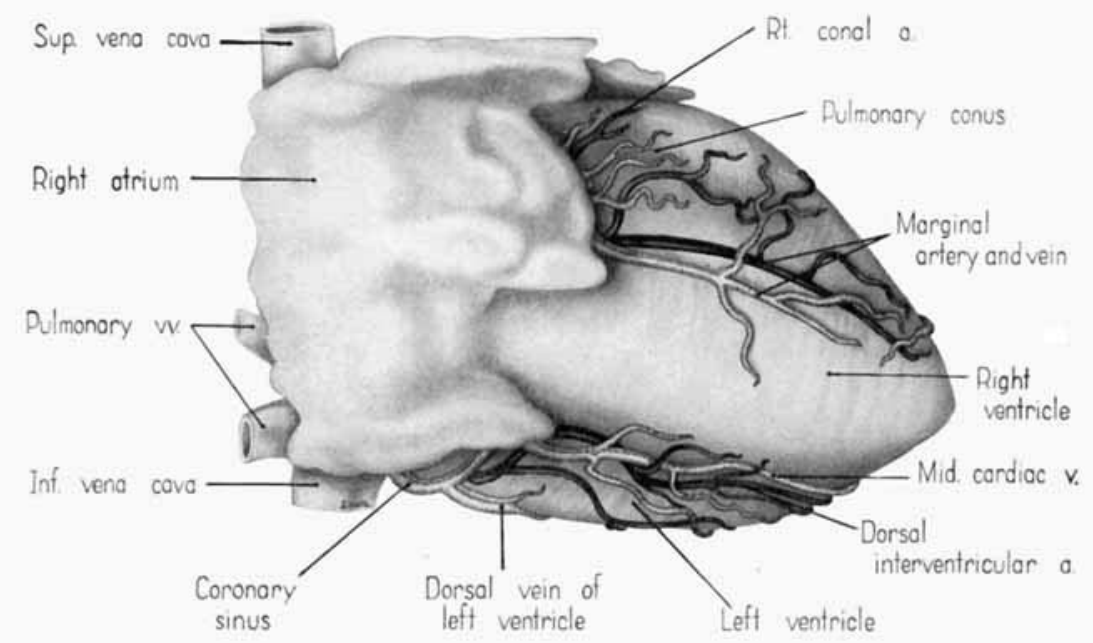

Fig. 2 Dextral view of heart of $31.5-\mathrm{mm}$ embryo, showing the superficial cardiac vessels. (Reconstruction $\times 100$, illustration $\times 34$.)

connective tissue. This mesenchymally packed space between the two leaves of the dorsal mesocardium forms an open route for the entrance of nerve fibers, as well as for the developing pulmonary veins. In embryos of the 9 th week the ingrowth of nerves by this route is extensive (fig. 15).

The regression of the left common cardinal vein has been accompanied by a gradual shift in the connective tissue within the mesocardium so that the membranes of this attachment now form duplicated pericardial reflections around the venous orifices. As a result a prominent fold is formed 
extending dorsally and to the left across the pericardial cavity. This plica of Marshall, or fold of the left superior vena cava as it is now usually called in adult anatomy, partitions the pericardial cavity into a well-defined transverse sinus (arrow in fig. 3) and a temporary retroplical space which will be

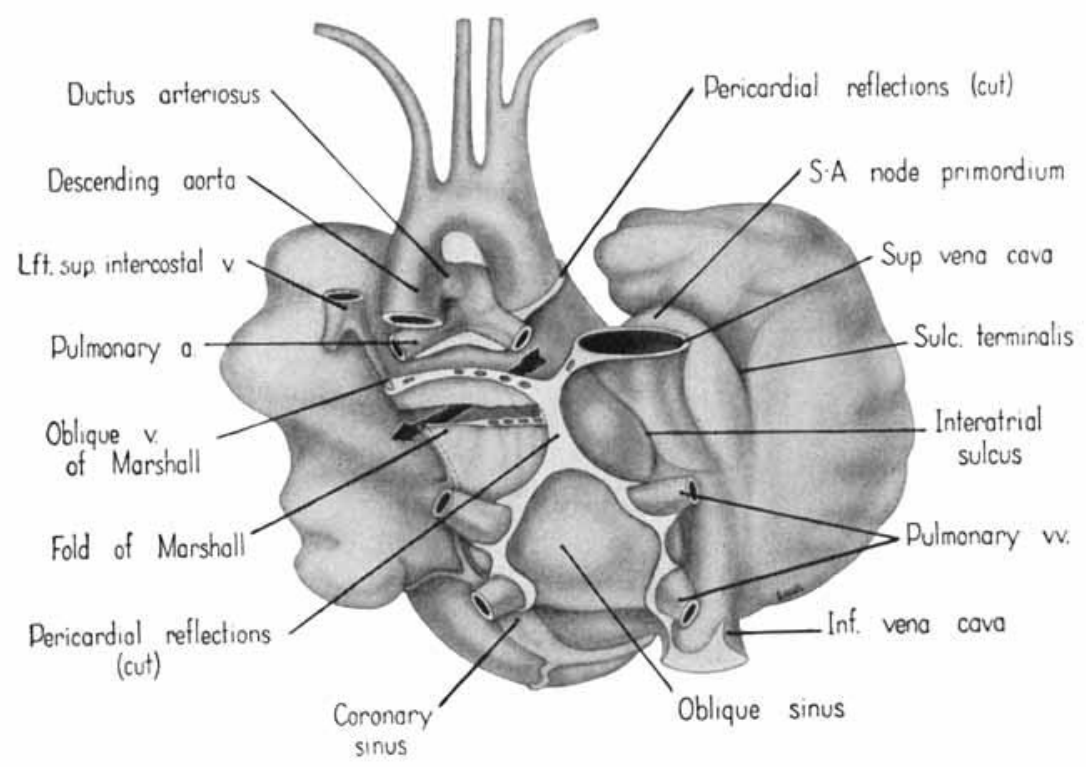

Fig. 3 Dorsal aspect of heart of $31.5-\mathrm{mm}$ embryo, showing the pericardial reflections where the heart was cut from the dorsal mediastinal wall. The fold of Marshall has been eut to show the transverse pericardial sinus (arrow). The course of the oblique vein within the fold of Marshall is indicated by interrupted lines. (Reconstruction $\times 100$, illustration $\times 34$.)

progressively obliterated by fusion of the plica to the dorsal body wall. The left, or free, margin of the fold contains a partly atrophied left common cardinal vein (oblique vein of Marshall, 1850). In its new position across the dorsal wall of the left atrium the left horn of the sinus venosus has assumed relations which identify it as the definitive coronary sinus. The primordial coronary sinus is, however, still connected distally with the much reduced, but patent, left common cardinal vein. 


\section{Internal organization of the heart}

Interatrial septal complex. Morphologically, the heart at the age under consideration and the postnatal heart differ most markedly in the organization of the interatrial septal complex. By the 9 th week, what was originally a common atrial chamber has been subdivided by the septum primum and the septum secundum (of Born). Although septum primum is the first part of the interatrial septal complex to make its appearance and is initially conspicuous, by the 9 th week it has been greatly reduced as a result of the formation of foramen secundum. Coincidentally its persisting basal portion has become fused to septum secundum. It is easier, therefore, to consider the organization of the interatrial septal complex at this stage by beginning with septum secundum, and then proceeding to the relations of what remains of septum primum on its left, and finally to the way in which the left venous valve becomes fused to its right atrial face.

Septum secundum develops in the relatively narrowed central portion of the primary atrial chamber. It lies in a plane between the venous mesocardium dorsally, and the ventral limit of the interatrial sulcus which is molded by apposition of the aortic trunk at this level. Septum secundum grows in this plane as a crescentic structure with one arm extending ventrally and the other cephalodorsally (figs. 4-7), thus forming the limbus foraminis ovalis. During development, the free muscular edge of the concavity of septum secundum is directed toward the inlet of the inferior vena cava. Because of the manner in which the caval stream, in the fetal calf heart, is apparently separated against this limbus into right and left moieties, Franklin ('48) calls this structure the crista dividens. Although this may be an excellent term from the functional standpoint in the fetus, it is less readily translated into adult anatomical terminology than is the older name limbus foraminis ovalis which is, essentially, retained for the structure familiar postnatally as the limbus fossae ovalis.

In the 9th week, the thickness of septum secundum is already one of its characteristic features. Ventrally, part of 
septum secundum blends into a poorly defined mass of loosely organized tissue in the floor of the right atrium involving the convergence of the sinus septum, and the regressed lower part of the left venous valve. Septum secundum has by no means completed its growtl so that the foramen ovale is still relatively large. As a result septum primum cannot function as a competent valve and there remains an unguarded

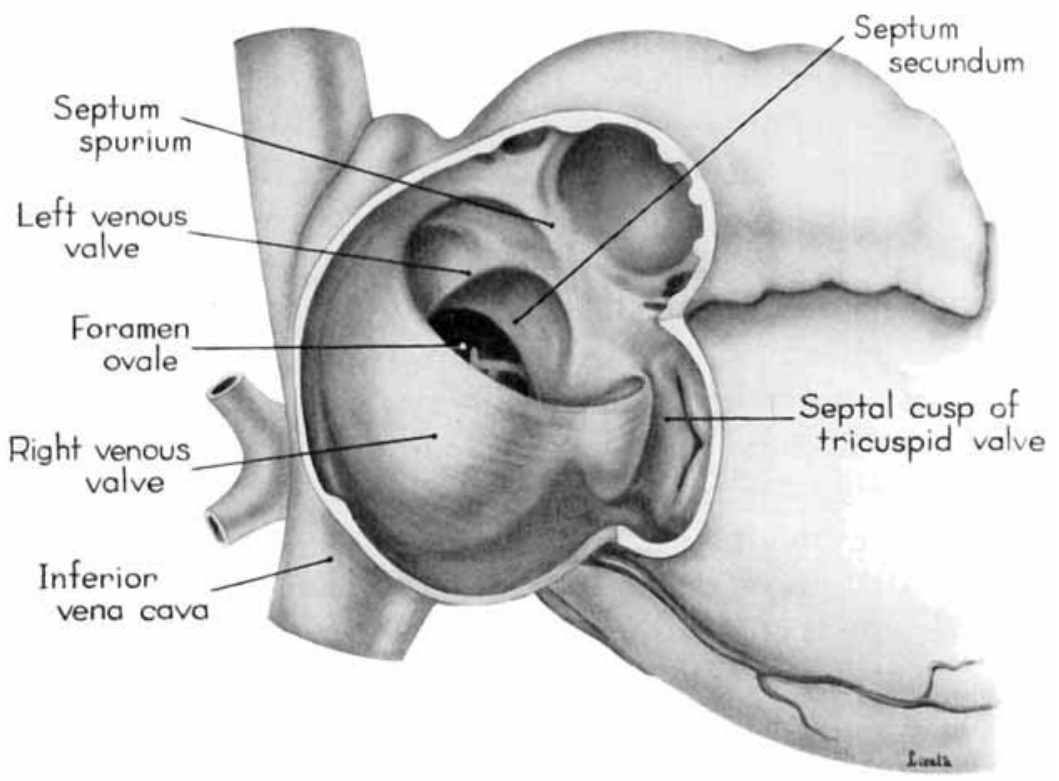

Fig. 4 Dextral view of heart of 25 -mm embryo with atrium opened. A tag of tissue which is atfached to the septum primum is just visible above the right venous valve. (Reconstruction $\times 100$, illustration $\times 40$.)

area where the two atria are in open communication by way of the foramen ovale in septum secundum and the foramen secundum in septum primum (figs. 5, 7).

In contrast to septum secundum, the persisting part of septum primum is relatively thin. This makes it possible for the transseptal blood flow to balloon it into the left atrium. For example, in the heart of a 25-mm embryo ( $\mathrm{EH} \mathrm{164),} \mathrm{septum}$ primum projects strikingly to the left, making for a free 
interatrial communication (fig. 8). In the same specimen the free edge of septum primum has an irregular tag of tissue attached to it which is suggestive of the net-like vestiges (Chiari, 1897) sometimes found in abnormal adult hearts. In the heart of a $31.5-\mathrm{mm}$ embryo (EH 377), however, septum primum covers a greater proportion of the foramen

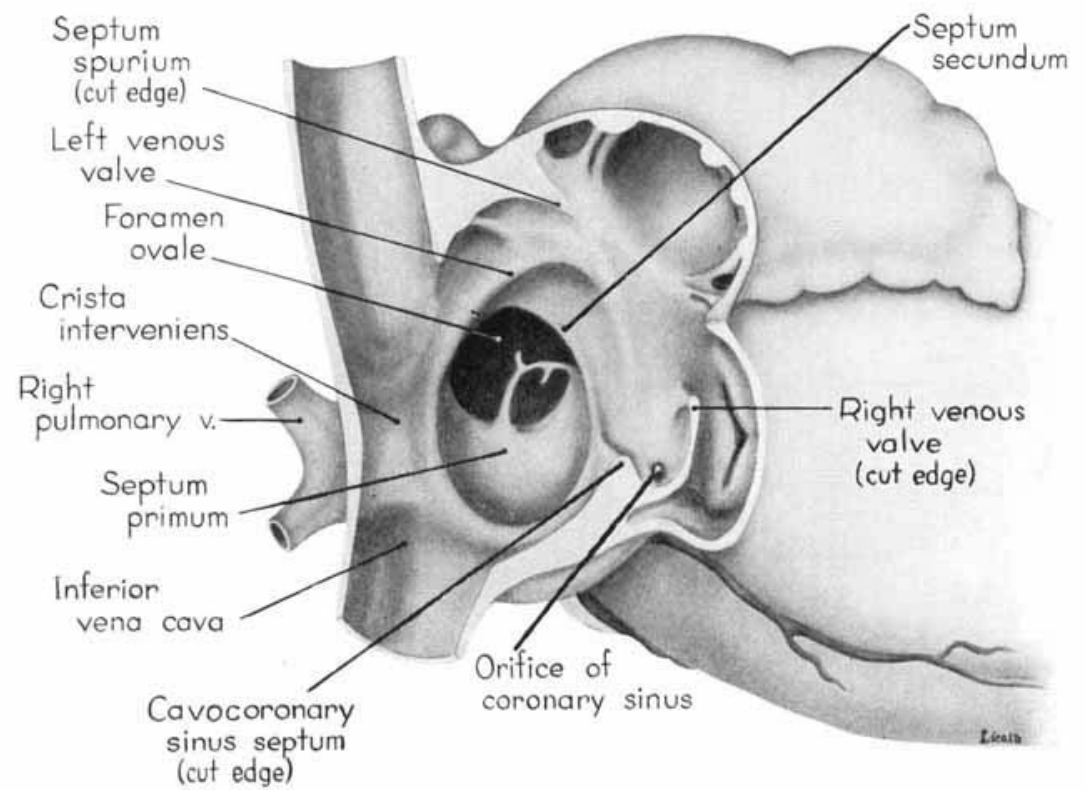

Fig. 5 Dextral view of heart of a $25-\mathrm{mm}$ embyy, with the right atrium opened, and the right venous valve cut away. The tag of tissue shown attached to septum primum is a result of irregular resorption in the formation of ostium II. (Recon. struction $\times 100$, illustration $\times 40$.)

ovale and has a free margin with a regular, crescentic contour (fig. 9).

Another significant relationship is that the opening, where the right pair of pulmonary veins become confluent as they enter the left atrium, is situated immediately adjacent to the base of septum primum on its left side. Not far to the left of the orifice of the pulmonary veins, a myocardial ridge traverses the floor of the atrium. This ridge is produced by 
the proximal part of the left horn of the sinus venosus which first becomes applied to, and later absorbed into, the atrial wall externally. This ridge helps to deepen the bay into which the right pulmonary venous flow enters. It seems not unlikely that the mounting return from the lungs tends to well into this bay and crowd the septum primum increasingly against

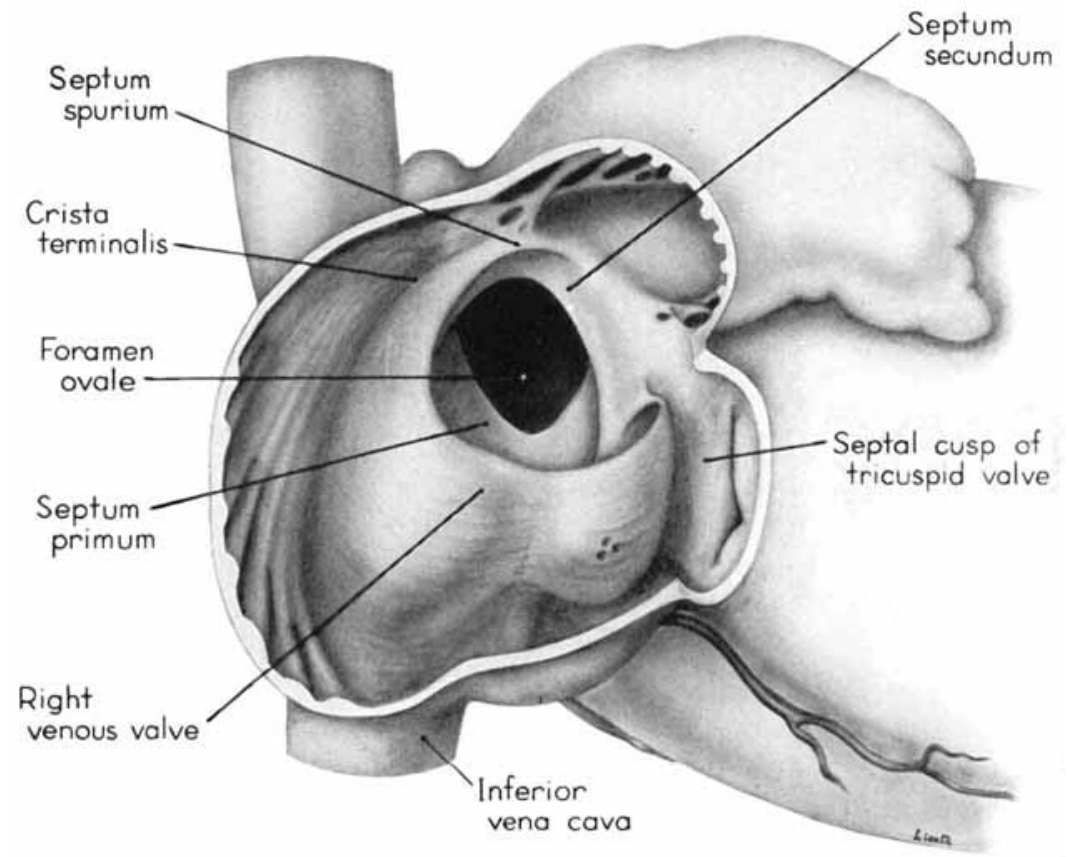

Fig. 6 Dextral view of heart of a $31.5-\mathrm{mm}$ embryo, with the right atrium opened. The lower part of the right venous ralve shows local areas of resorption. (Reconstruction $\times 100$, illustration $\times 35$.)

septum secundum as development advances. The postnatal increase in pulmonary return into this region might well be one of the ancillary factors in paving the way for the functional closure of the foramen ovale following birth.

Sinus venosus, venous valves, and septum spurium. During the early stages of cardiac development the vaguely defined territory where the great veins become confluent to 
discharge into the heart is called the sinus venosus. Shortly after its establishment the orifice of the sinus is gradually shifted out of its original midline position to empty into the right atrium. This orifice is guarded by two conspicuous folds,

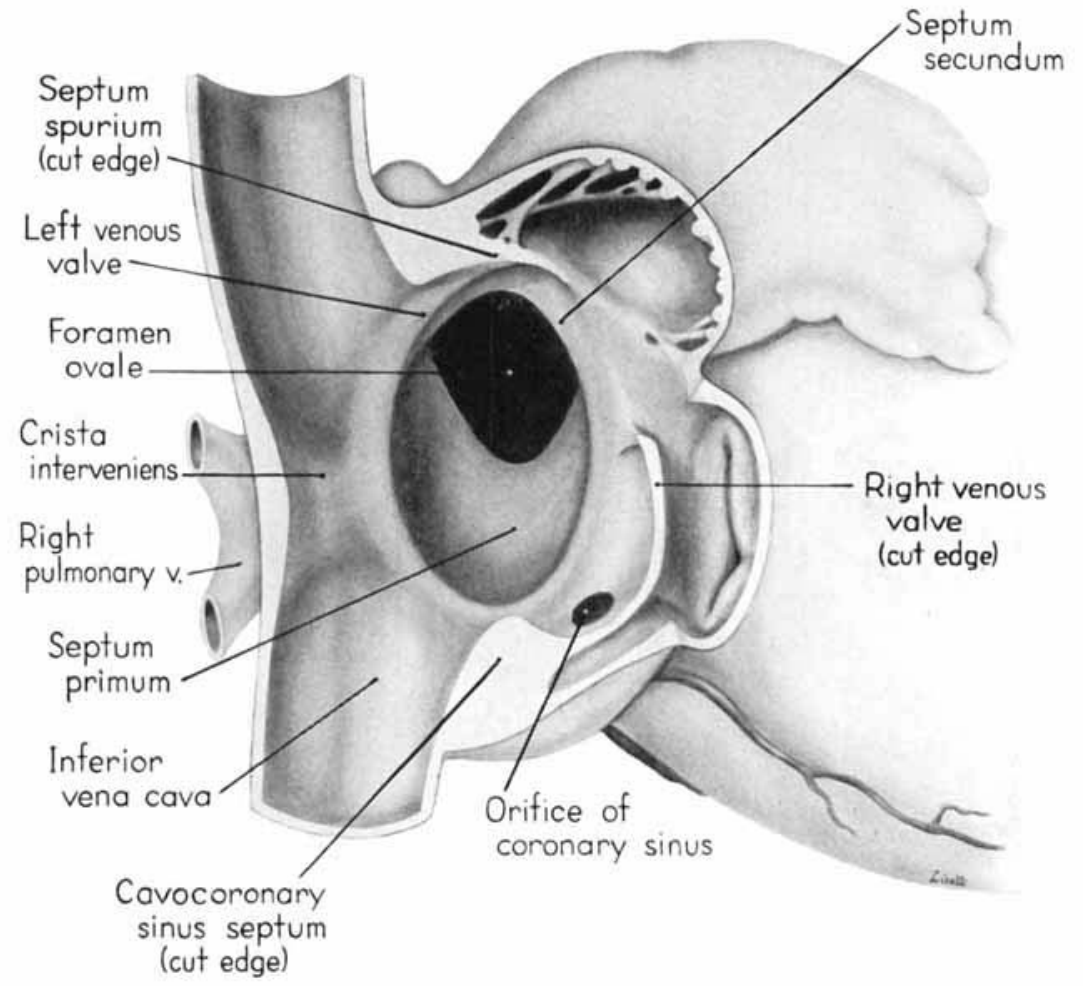

Fig. 7 Dextral view of heart of $31.5-\mathrm{mm}$ embryo with the right atrium opened and the right venous valve removed. (Reconstruction $\times 100$, illustration $\times 35$.)

the right and left venous valves, or valvulae venosae. The venous valves meet along the roof of the right atrium in a prominent ridge to form the septum spurium. As the sinus venosus becomes incorporated into the dorsal part of the heart, the septum spurium projects progressively farther into the right atrium forming the right boundary of a territory which may be designated as the sinal bay of the right atrium. 
In embryos of the 8th and 9 th weeks this bay is strikingly deep because of the strongly developed right venous valve which is continuous with the septum spurium (figs. 4, 6). The sinal bay is bounded medially by a much reduced left venous valve and the developing interatrial septum secundum adjacent to which this valve has come to lie (figs. 5, 7).

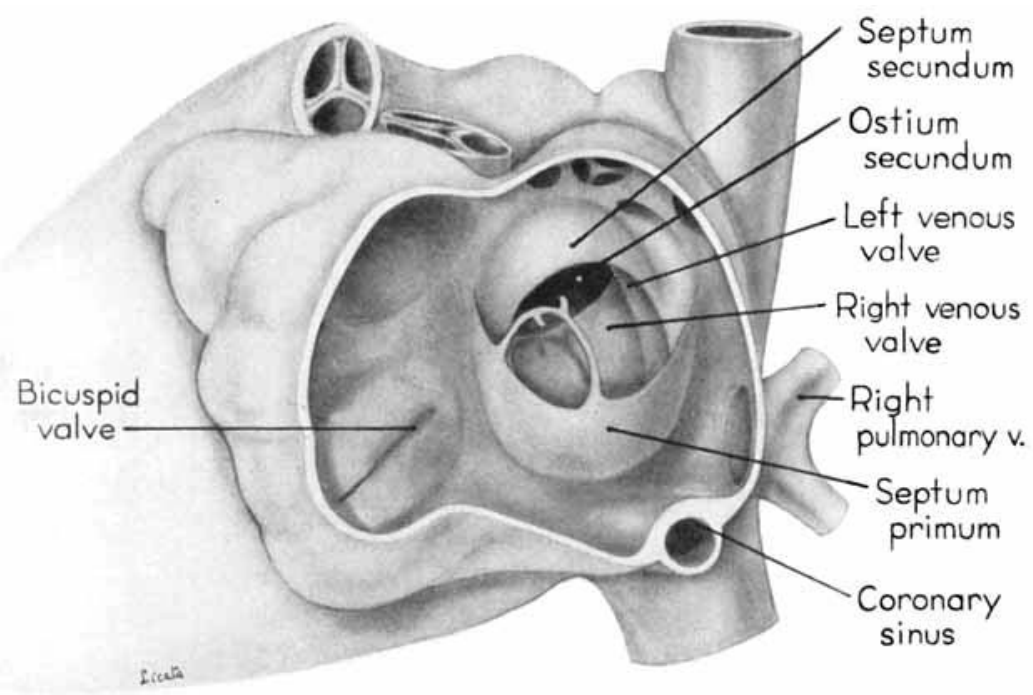

Fig. 8 Sinistral view of heart of a $25-\mathrm{mm}$ embryo with the left atrium opened to expose the interatrial septal complex. (Reconstruction $\times 100$, illustration $\times 40$.)

During development, the regressing left venous valve becomes increasingly closely related to septum secundum. Its primary association with the right venous valve and septum spurium makes it desirable to consider first this relationship. At the beginning of the 9th week, a cleft-like recess is present between the upper part of the left venous valve and interatrial septum secundum. This recess is a remnant of an originally wider atrial pocket designated as the spatium interseptovalvulare (Tandler, '12). At earlier stages the cephalic limit of the left venous valve could be clearly identified as the point where it met the right venous valve to form septum spurium. By 9 weeks, however, the regression of the most 
cephalic portion of septum spurium is well advanced, and what remains of it has, for the most part, fused with septum secundum, so that considerable obliteration of the spatium has occurred. The upper part of the left venous valve also is involved in the fusion and as a consequence it has become directly adherent to the developing septum secundum in this

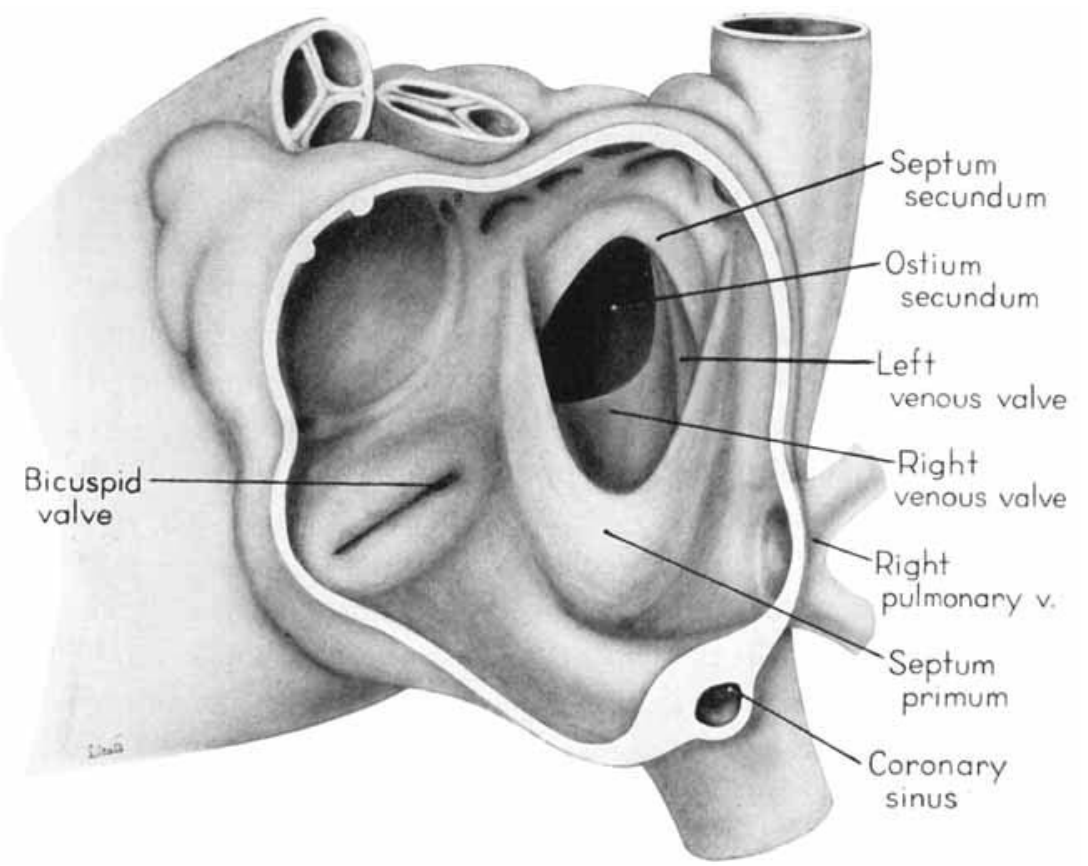

Fig. 9 Heart of a $31.5-\mathrm{mm}$ embryo with the left atrium opened to show the interatrial septal complex in sinistral view. (Reconstruction $\times 100$, illustration $\times 35$.

region. The progressive fusion of this part of the valve to the septum, accompanied by regression of the valve itself, results in further reduction of the spatium. Moreover, from an early age the left valvula has been lagging behind the right in rate of growth. As a result, in comparison with the highly developed right venous valve, the left valve at this stage is strikingly small (cf. figs. 4, 5). Its further regression is 
presaged by the fact that what remains of it has become relatively thin. Caudally, the valve has become even more markedly reduced and has fused almost indistinguishably with septum secundum around the caudal margin of the foramen ovale so that the valve and septum appear to merge in this area (figs. 5, 7).

The right venous valve regresses much later than the left. During the 8th and 9th weeks, it has a height which, in dextral view of the opened right atrium, almost completely obscures the foramen ovale (figs. 4,6). At this age the valve deepens the sinal bay of the right atrium sufficiently to form a baffle which may well be a factor in routing a considerable proportion of the caval blood into the left atrium by way of the wide, poorly guarded interatrial orifice. The mural attachment of the valve is along the medial margin of a muscular band developed in the atrial wall which becomes the definitive fasciculus terminalis. Throughout its course the embryonic fasciculus terminalis sends out smaller muscular bands (taeniae musculari) into the atrial walls. These are the primordia of the pectinate fasciculi.

In the floor of the atrium the right venous valve skirts the right margin of the inferior caval inlet and thence continues along the lateral margin of the coronary sinus inlet. Between these venous orifices it is bound to the base of the interatrial septal complex by a growing band of young connective tissue, the "Querfalte" of Born (1888), or the "sinus septum" of Tandler ('12). Since this structure might be designated more precisely as the "cavocoronary sinus septum," because of the way it separates these two orifices and their valves, this term is adopted here.

In younger embryos the point within the pars confluens of the sinus venosus, where the left horn originally met the right, is marked by a ridge. This mass is the primordium of the cavocoronary sinus septum. With the later shift of the orifice of the sinus venosus into the right atrium the ridge appears to arise from the inferior medial aspect of the floor of the sinus and continues to grow toward the caudal part of the 
right venous valve which it eventually meets. The subsequent fusion of these two structures progresses from the base to the free edge of the valve.

At the beginning of the 9 th week this fusion has involved approximately one-half of the width of the valve at its point of junction with the sinus septum (fig's. 4,6). With later extension of this fusion toward the free edge of the valve a partiation is thus formed, completely separating the inferior caval inlet from the orifice of the coronary sinus. This cavocoronary sinus septum at the same time subdivides the right venous valve into a large upper, and a small lower component. The Eustachian valve of the inferior vena cava will be derived from the unresorbed part of the upper portion of the right venous valve, while the Thebesian valve of the coronary sinus will be derived from what remains after resorption of the lower portion.

Even at this early stage, a tendinous cord in found developing in the upper part of the cavocoronary sinus septum which is retained and further developed in the adult heart as the tendon of Todaro (1877). A second strand of tendinous tissue develops at the line of fusion of the sinus septum with the right venous valve. The tendon of Todaro as recognized in the adult, therefore, appears to be a three-limbed structure. The main limb proceeds from the ventral pillar of the limbus fossae ovalis to divide into two secondary limbs at the sinus septum, one inserting in the Eustachian valve, the other diving deep into the floor of the atrium between caval inlet and coronary sinus orifice.

At the beginning of the 9 th week a few minute, thinned areas appear in the marginal portions of the right venous valve. In somewhat older embryos these thinned areas develop into perforations. Still a little later, the coalescence of these originally isolated perforations leads to the resorption of large marginal areas of the valve. This manner of reduction of the marginal parts of the right venous valve in giving rise to the Eustachian and Thebesian valves undoubtedly accounts for the frequency with which these valves in the adult 
exhibit multiple small perforations, especially near their margins. The extensive net-like vestigial structures occasionally found in the right atrium of adult hearts (first described by Chiari, 1897), are a result of incomplete resorption of the right venous valve in the process that normally reduces it to the small valves of the inferior vena cava and the coronary sinus.

The ventricles and atrioventricular valves. The histogenesis of the atrioventricular junction has received little attention since the work of Kent ('13, '14). During early stages the atrial portion of the heart is delimited from the ventricles externally by a progressively deepening atrioventricular groove. This same area is marked internally by a narrowing of the cardiac lumen to establish the atrioventricular canal. Growth and subsequent fusion of the dorsal and ventral endocardial cushions in this primary common atrioventricular canal establish separate right and left orifices. This partitioning mass of embryonic connective tissue is located between the interatrial septal complex and the growing interventricular septum musculare. It is continuous laterally with the histologically similar, but less thick, tissue lining the entire circumference of each of the atrioventricular orifices. Coincident with these internal changes, the embryonic epicardial connective tissue in the atrioventricular sulcus begins to cut progressively deeper into the heart wall, thus initiating the separation of the atrial myocardium from that of the ventricles.

By the 9th week the atrioventricular junction shows well advanced histogenetic changes. The myocardium is compressed between the encroaching epicardial and endocardial loyers of connective tissue at the atrioventricular junction, and in that zone slows the beginning of atrophy. The cytoplasm of the muscle fibers has diminished, and the enlarged interstices between the fiber's are occupied by a homogeneous matrix. The endocardial cushion tissue, lying internally, is more richly cellular where it is situated immediately adjacent to the myocardium. Externally, in the atrioventricular sulcus, cells within the deeper layers of the epicardial connective tis- 
sue have also apparently begun to proliferate in many places. Embryonic fibroblasts from the rapidly proliferating endocardial and epicardial connective tissues have migrated into the interstices between the atrophic myocardial fibers. This process is the initial phase in the formation of the atrioventricular annuli fibrosi although the fibers associated with these cells at this age are still relatively sparse and slender.

Toward the end of the 7th week, the interventricular foramen was completely occluded by a mass of endocardial cushion tissue. This tissue was derived from three separate sources: (1) the tubercles of the fused atrioventricular canal cushions; (2) the conus ridges; and (3) the crest of the interventricular septum (Odgers, '38; Kramer, '42). By the 9 th week, two flanges from this composite mass extend laterally into the atrioventricular canals. The central and main portion of this mass of richly cellular embryonic connestive tissue extends over the entire crest of the muscular part of the interventricular septum. Where it comes into relation with the atrioventricular bundle, however, it becomes rather more loosely organized and is continuous with the developing connective tissue sheath of the bundle. Later this central area of embryonic connective tissue will become thimner and more densely woven, and give rise to the septum membranaceum. The thinning is accomplished in part by this process of connective tissue concentration and in part by the undercutting of the main mass to form flange-like projections into the atrioventricular canals. The right flange is the primordium of the medial (septal) cusp of the tricuspid valve, while the left flange is the primordium of the anterior (septal) cusp of the bicuspid valve.

At this age the interiors of the ventricles are richly trabeculated, giving them a labyrinthine appearance. The compact layer of the left ventricular wall, however, appears to be somewhat thicker than that of the right, although the over-all thickness is approximately equal in the two ventricles. Many of the more massive trabeculae are connected to the ventricular faces of the atrioventricular valve primordia (fig. 
10). The framework of the cusps of the developing atrioventricular valves consists of two different components. A layer of endocardial cushion tissue lies beneath the atrial endocardium, while the tissue deep to the ventricular endocardium consists of a muscular lamina anchored by massive chordae carneae. With the subsequent regression of the cardiac muscle fibers from the ventricular surfaces and their replacement by collagenous fibers the valve cusps are established. The anchoring trabeculae at their valvular ends undergo similar histological changes, thus giving rise to the chordae tendineae. The mural ends of the muscular trabeculae, however, are retained as primordia for the papillary muscles.

Aortic and pulmonary outlets. The truncoconal junction represents the future division between the ventricles of the heart and the arterial trunks which arise from them. The histogenetic changes pertaining to the aortic and pulmonary outlets in some respects correspond to those which oceur at the atrioventricular junction. A basic distinction lies in the fact that the former involves a separation of atrial from ventricular myocardium. Externally the truncoconal junction is marked by a slight constriction (fretum Halleri, Haller, 1786) which partly results from a thinning of the epicardial connective tissue at this level. The most striking histological change at this age is the progressive regression of myocardium at, and above, the truncoconal junction. This process is characterized by marked atrophy of the cardiac muscle fibers accompanied by increase in connective tissue, and later in the smooth muscle of the developing media of pulmonary trunk and ascending aorta.

Internally the truncoconal junction is ringed by richly cellular endocardial cushion tissue which serves as the basal

Fig. 10 Photomicrograph $(\times 42)$ showing the developing tricuspid valve in a $31.5-\mathrm{mm}$ embryo. Note the endocardial cushion tissue on the atrial faces, and the regressing myocardium on the ventricular faces of the leaflets. Abbreviations: $E$, endocardial cushion tissue; LA, left atrium; $L V$, left venous valve; $M$, myocardium; RA, right atrium; RV, right venous ralve; $S I$, septum primum ; $S$ II, septum secundum; T, tricuspid valve. 


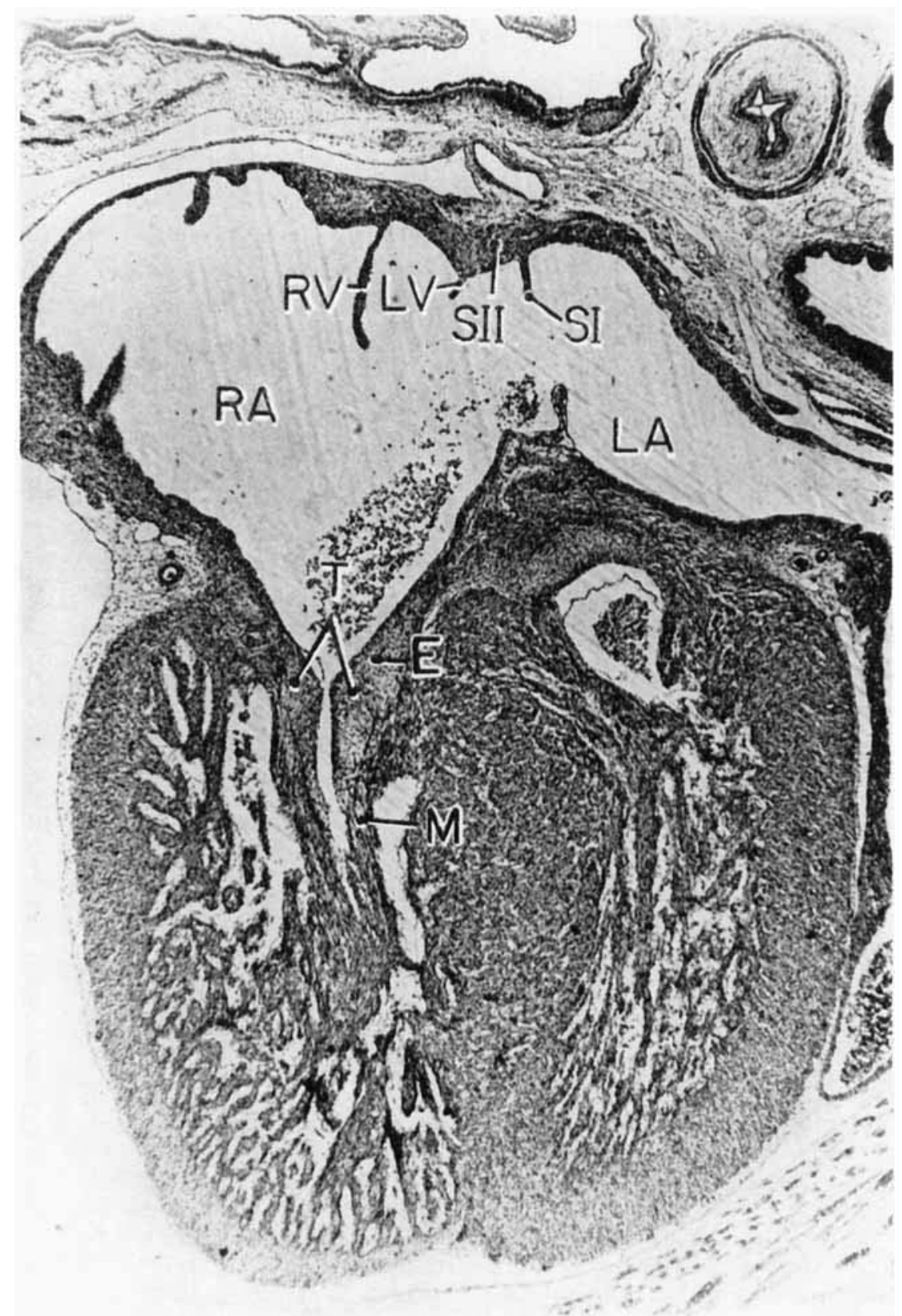

Figure 10 
attachment for the cusps of the semilunar valves (fig. 11). This annular concentration of rapidly proliferating embryonic connective tissue represents, in both the aortic and pulmonary trunks, the precursor of the fibrous annulus. The nuclei of these fibroblasts are large and strongly basophilic. Many fibroblasts migrate into the interstices between the atrophic muscle fibers; a few come into this same zone from the epicardial embryonic connective tissue. A cord of proliferating fibroblasts connects the aortic and pulmonary annuli and represents the future pulmono-aortic ligament (tendon of the conus).

The primordial cusps of the aortic and pulmonary semilunar valves are derived from endocardial cushion tissue elaborated from the truncus ridges (Kramer, '42). At this age these cusps consist of endothelially covered, cup-shaped masses of embryonic connective tissue which, although relatively short and thick (fig. 11), appear to be functionally effective. The free edge of each cusp of the semilunar valves has a button-like thickening characterized histologically by a whorl of fibroblasts. This concentration of cells constitutes the primordial tissue of the nodulus Arantius of the adult.

The walls of the ascending aorta and pulmonary trunk are richly cellular and so compact that definite orientation of the muscle elements was difficult to make out. In general, the muscle appeared to have a circular to spiral arrangement. The distal end of the pulmonary trunk is marked by a prominent dilation at the point where it gives off the pulmonary arteries. The ductus arteriosus takes its origin from this site and proceeds, with an inclination toward the left pulmonary artery, to join the aorta.

Fig. 11 Photomicrographs showing the developing pulmonary semilunar valves in a $31.5-\mathrm{mm}$ embryo.

A. Low magnification $(\times 45)$ of section, passing through semilunar valves and ductus arteriosus, for general topography. A, aorta; C, ducto-aortic erista (crista reuniens); $D$, ductus artexiosus; $J$, juxtaductal body; $P$, pulmonary trunk.

B. Developing valve leaflet $(V)$ more highly magnified $(\times 85)$. This section shows, also, the truncoconal junction, characterized at this stage by regressing myocardium ( $R$ ) and the endocardial cushion tissue of the developing fibrous annulus at the bases of the semilunar valve cusp. 


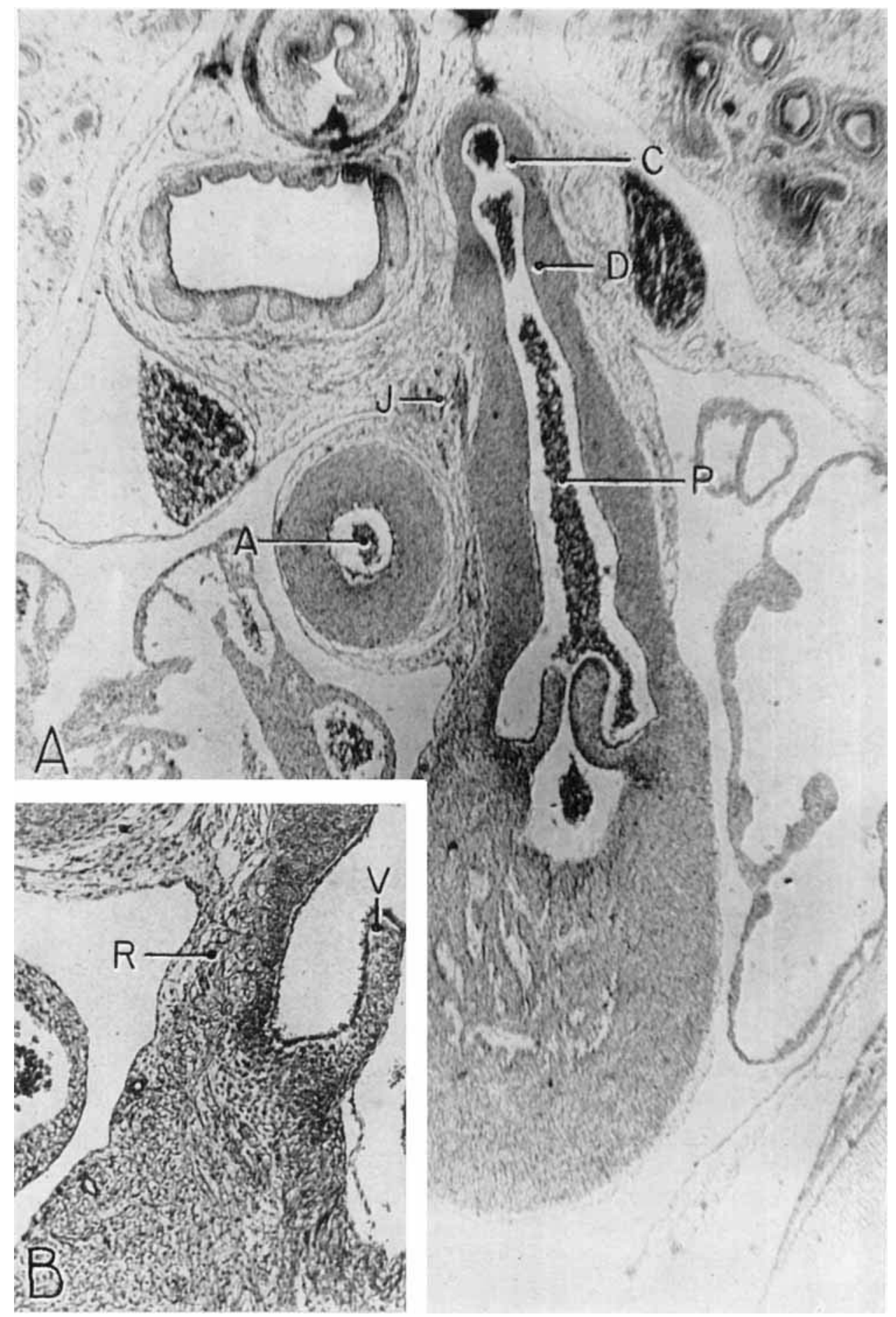

Figure 11 
In both the hearts which were reconstructed the ductus appeared to have been fixed in a contracted state, for the lumen in each was markedly narrow and the wall relatively thick. Subendothelially, a mucoid substance could be seen as a delicately outlined intimal stratum. In general, the layers of embryonic muscle fibers constituting the wall of the ductus appeared to have a helicoid arrangement. At the point where the ductus joins the aorta the muscle fibers are so arranged that a crescentic flange (fig. $11 \mathrm{~A}$ ) extends from the cephalic rim of this junction. This flange has been observed also in the fetal lamb (crista reuniens, of Barclay, Franklin and Prichard, '44). In this paper it will be referred to as the crista ducto-aorticus.

\section{Coronary circulation}

Study of the blood supply of the myocardium was carried back into stages younger than those reconstructed. The coronary arteries appear at the transition from the 6th to 7 th week as solid angioblastic buds and, once established, extend rapidly through the epicardial layer of the heart. The cardiac veins slightly precede the arteries in their development.

By the 9th week practically all the major branches of the coronary arteries characteristic of the adult heart are represented (figs. 1, 2). From its origin the right coronary artery extends into a relatively thick mass of embryonic connective tissue which lies in the depression between the right atrium and the conus. Among the first branches to leave it is one supplying the primordium of the sino-atrial node (fig. 12). This vessel courses within the groove between atrium and conus whence it crosses over the atrial wall to penetrate the nodal primordium at its medial aspect. This region of the nodal primordium is the point of convergence, not only for the principal blood vessels but also, as we shall see later, of important nerves. Within the body of the node the artery bends sharply, and then follows the right limb of the sinoatrial fasciculus. Before the nodal artery loses itself within this tissue, however, it contributes fine twigs to a pericaval 
arterial annulus. Lower in the sulcus terminalis a stout branch (ramus fasciculis terminalis) leaves the main ressel to penetrate the crista terminalis. Within the sinus wall, capillaries from the nodal artery enter into a plexus in common with capillaries connecting' with atrial "Thebesian", veins (Geraudel, '28). These vessels which open into the interior of the atrium are the principal means of drainage for the node.

A second atrial branch leaves the right coronary artery as it enters the atrioventricular sulcus and arborizes extensively within the atrial wall. From here the main artery courses within the atrioventricular sulcus to the dorsal aspect of the heart, finally reaching the point of intersection of the atrioventricular sulcus with the principal axis made by the interatrial and interventricular sulci - a region sometimes called the crux (Haas, '11). At the crux the artery turns sharply to course within the interventricular sulcus as the dorsal (posterior) descending artery. A small but important branch leaves the right coronary artery near the crux to penetrate the heart wall at the atrioventricular junction. This is the ramus septi fibrosi (Tawara, '06; Moenckeberg, '08; Haas, '11) or the first dorsal perforating septal branch (fig. 13). This vessel passes to the cephalodorsal part of the interventricular septum where it divides into two principal branches. A left branch plunges directly into the primordial mass of the atrioventricular node. A second branch deviates to the right where it comes into relation with the main bundle of His. In addition, this area of the septum is pervaded by a rich capillary plexus drained by myocardial sinusoids which open into the right and left ventricular chambers. A striking feature of the ramus septi fibrosi is its relatively poor development in comparison with the right nodal artery.

The left coronary artery turns sharply at its origin to descend into the conoventricular groove. Within the groove it divides into a ventral (anterior) descending, and a circumflex branch (fig. 12). The ventral descending branch has a comparatively direct course in the ventral interventricular 
sulcus and appears to be the best developed of the cardiac vessels. The principal vessels which leave it consist of superficial epicardial twigs and deep ventral perforating septal branches. Its terminal portion extends around the incisura apicis cordis to anastomose with the dorsal (posterior) descending branch of the right coronary artery. The left conal branch leaves the main artery shortly after it enter's the

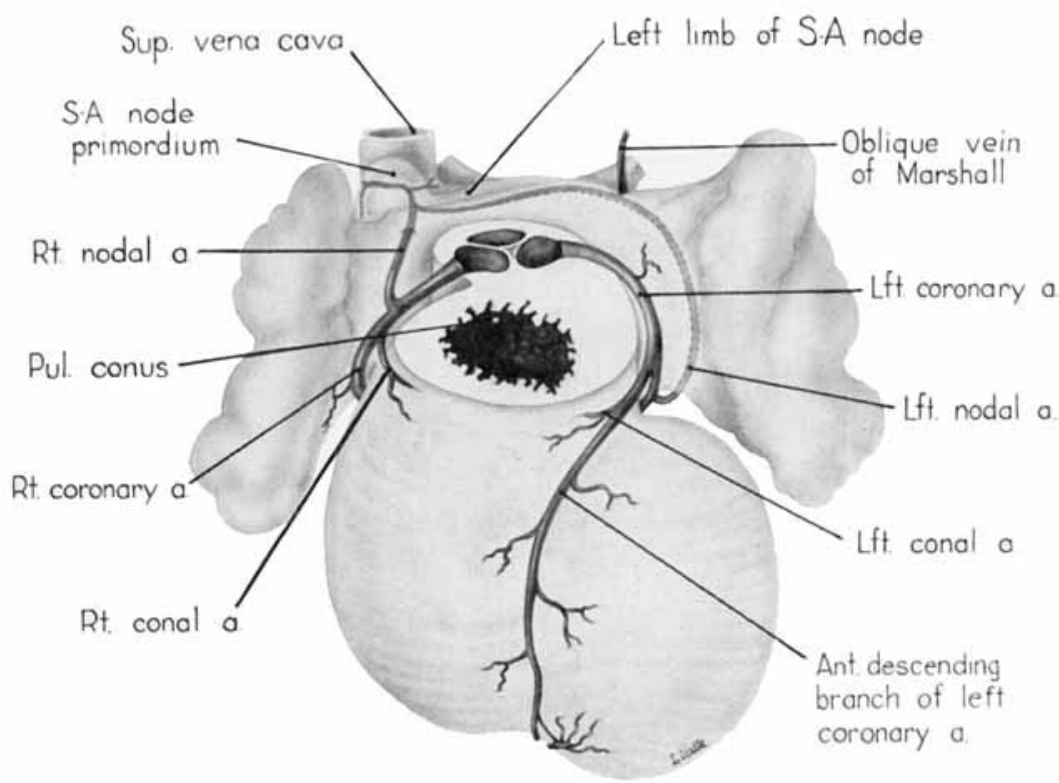

Fig. 12 Semischematic diagram to show the branches of the coronary arteries which supply the sino-atrial node. The heart has been eut at the level of the aortic valve and the pulmonary conus.

sulcus (fig. 12). The conal artery almost immediately penetrates the conus musculature. It main intramural branch follows the right branch of the bundle of His and finally extends into the moderator band. This vessel (fig. 13) may be designated appropriately as the artery to the right branch of the His bundle or ramus limbi dextri of Gross ('21). A homologous conal branch arises from the right coronary artery but has a much less extensive distribution than the left. 
A variable branch to the sino-atrial node may arise from the left circumflex artery just as it enters the sulcus. In the heart of the 25-mm embryo this left nodal artery was clearly defined (fig. 12), but in the 31.5-mm embryo it showed definite signs of deterioration. Shortly beyond its origin the left

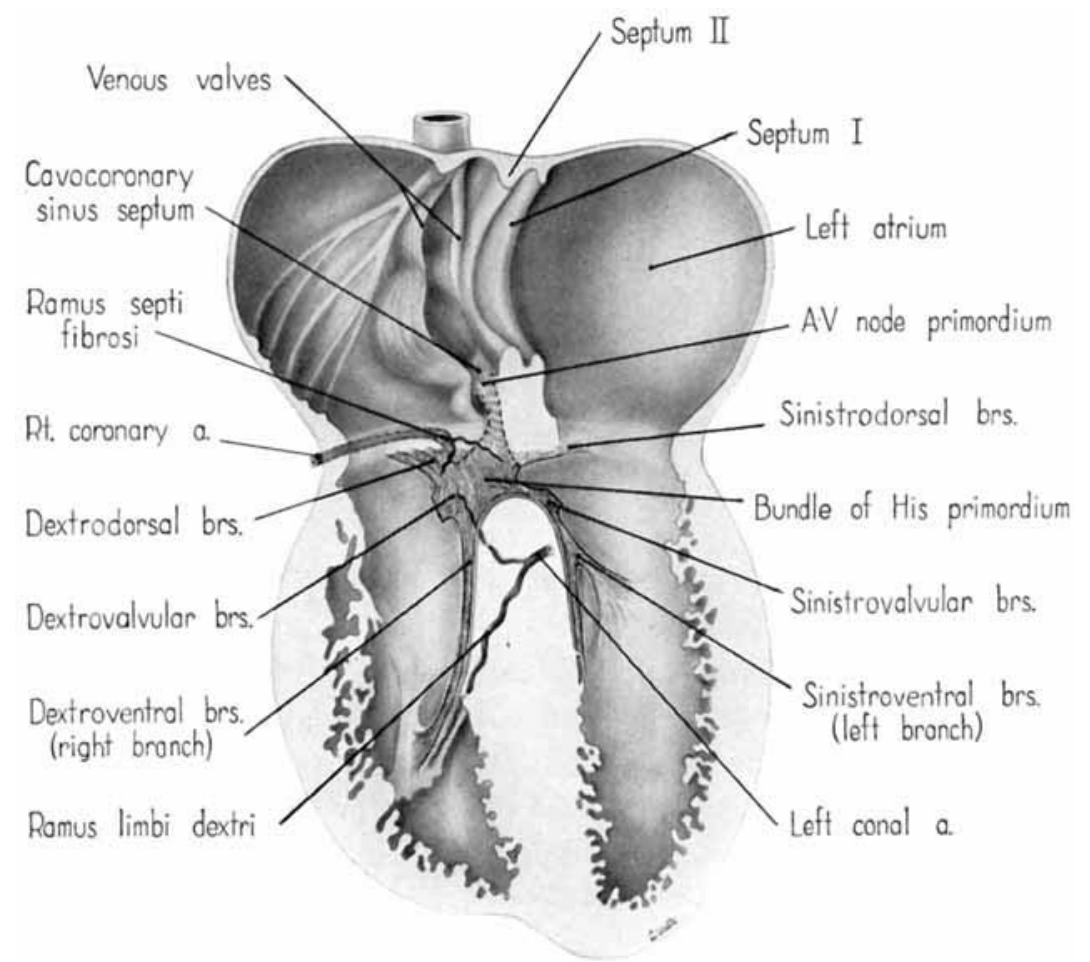

Fig. 13 Semischematic diagram to show the branches of the coronary arteries supplying the bundle of His and its main branches. The illustration was drawn as if the composite mass of endocardial cushion tissue which oceludes the inter. ventricular foramen had been completely removed to expose the bundle of His.

nodal artery penetrates the atrial wall just lateral to the entrance of the left pair of pulmonary veins. Thence it passes ventral to the oblique vein of Marshall and courses deep within the atrial musculature in the direction of the right superior vena cava. In the heart of the $25-\mathrm{mm}$ embryo which was reconstructed and in some other specimens examined, 
this vessel was contained in a muscular trabecula which bulged into the atrial chamber. Just medial to the sino-atrial node this vessel sometimes anastomoses with the right nodal artery, or in other hearts may constitute the exclusive blood supply to the node. The node thus may be supplied by either a right or left nodal artery, or by both.

Attention already has been drawn to the fact that the primordial cardiac venous plexus precedes the coronary arteries in development. It will be recalled, also, that the cardiac veins and their tributaries were established early in the 6th week by endothelial sprouts which arose directly from the coronary sinus and spread rapidly within the epicardium. By the $31.5-\mathrm{mm}$ stage, all the major cardiac veins familiar in the adult are represented (figs. 1,2). The middle cardiac vein and the dorsal vein to the left ventricle are among the earliest of these vessels to develop. The primordia of the great (left) and small (right) cardiac veins are also clearly present at this age.

In addition to the cardiac veins which drain into the coronary sinus, a special, independent set of veins arises in relation to the right atrial wall. These are the ventral (anterior) cardiac veins, or venae parvae cordis. These vessels appear to develop relatively late as endocardial diverticula from the atrial lumen, secondarily establishing connection with the epieardial venous plexus. The special atrial branches originally described by Cruveilhier (1849) and Zuckerkandl (1881) could not be clearly identified and must be presumed to arise at later stages.

\section{Innervation}

In dealing with the innervation of the adult heart it has become customary to refer to a superficial and a deep cardiac plexus. In the developmental phases of cardiac innervation, however, a different terminology seems more appropriate. In the present work, the term "truncoconal cardiac plexus" is used instead of "superficial cardiac plexus," and "sinoatrial cardiac plexus" instead of "deep cardiac plexus." 
The following account of the related changes which set the stage for the establishment of cardiac innervation brings out the factors which led to the adoption of this terminology.

In the early stages of heart formation, the condensed mesenchyme within the original dorsal mesocardium was utilized by nerve cells and fibers as an avenue of ingress to the heart. Postganglionic sympathetic neurons enter from cervical and thoracic levels. Terminal parasympathetic ganglion cells migrate along the path of the cardiac branches from the vagi. Later, with the formation of the transverse pericardial sinus, the primary dorsal mesocardium becomes divided into arterial and venous components. Thus, one set of nerves passes through the arterial mesocardium to reach the truncoconal end of the heart, while another set enters through the venous mesocardium to reach the sinus venosus and the atria. It is, therefore, appropriate to speak of the former as the "truncoconal cardiac plexus" and the latter as the "sinoatrial cardiac plexus." In this connection it should be mentioned that His, Jr. (1891, 1897), in his classic treatises on the development of the cardiac nerves, and the development of the sympathetic nervous system in vertebrates, designated these cardiac nerve plexuses as the "Bulbusgeflecht" and the "Vorhofsgeflecht," respectively. In the same work he refers to a "Verbindungsgeflecht," which connects the two in the mediastinum. The present study did not deal with sufficiently early stages to throw any further light on the origin of the "Verbindungsgeflecht" of His. It seems probable, however, that this plexus is the forerunner of the pulmonary plexus. Since the pulmonary circulation is relatively new in phylogeny, it is plausible that with the development of the pulmonary arteries and veins in the mediastinum, a secondary nerve plexus should be established about them having connections with the two adjacent primordial cardiac plexuses.

During the 6 th week the truncus ridges have met each other to partition the lumen of the originally common truncus arteriosus. By the 9th week the walls of the aortic and pulmonary components have been reorganized. In this process 


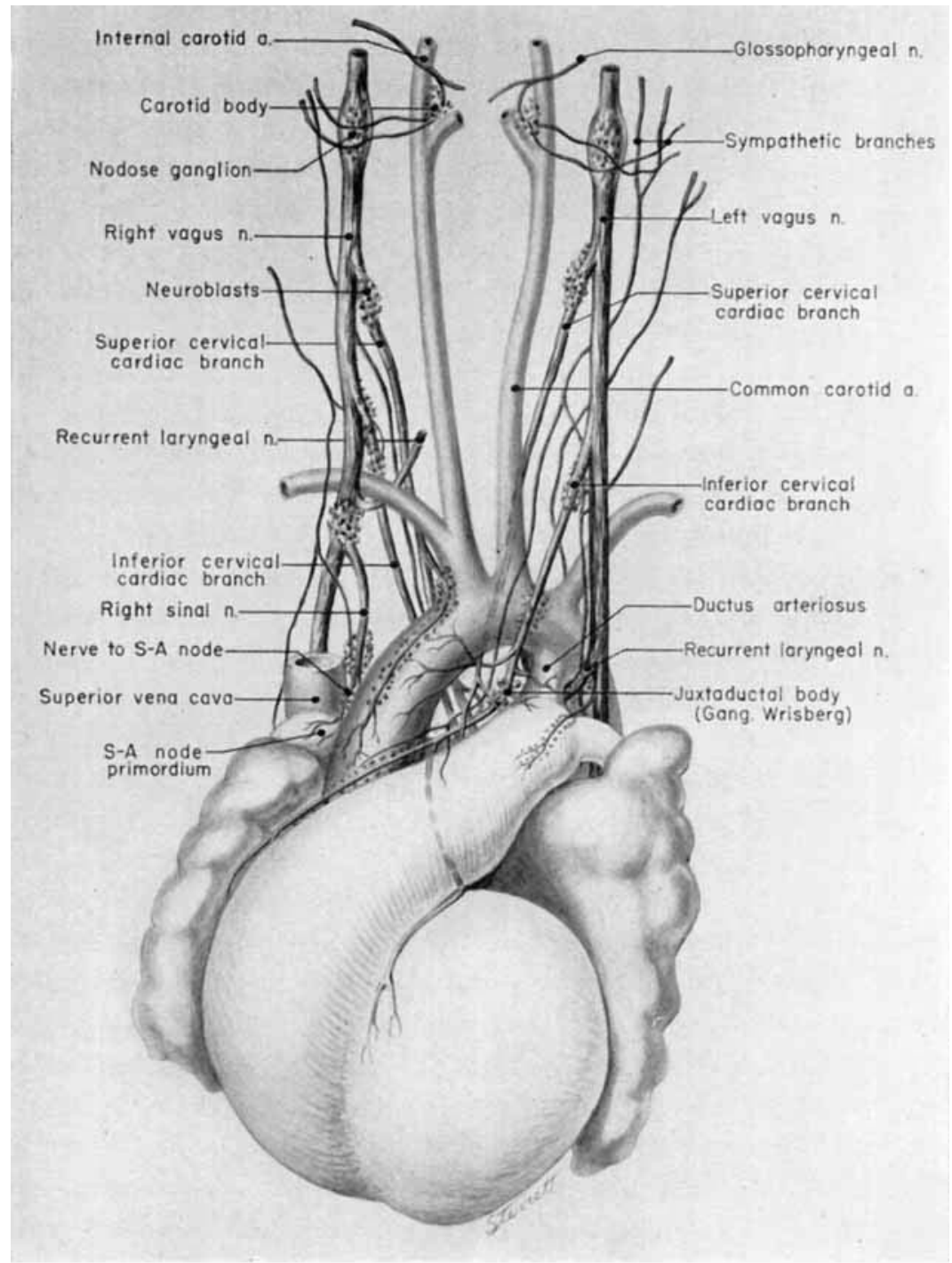

Fig. 14 Ventral aspect of leart and great vessels of a $31.5-\mathrm{mm}$ embryo, showing the distribution of the cardiac nerves and ganglia. (Reconstruction $\times 100$, illustration $\times 50$.$) For greater clarity, the vessels and nerves cephalic to the$ heart have been represented as if pulled out somewhat longer than their true proportions. The aortic areh is shown as if drawn craniad so the relations of the ductus arteriosus and the nerves could be more readily shown. 
the original truncoconal plexus becomes modified into a plexus around the ascending aorta and the pulmonary trunk. There is less modifieation of the original sino-atrial plexus about the venous end of the heart.

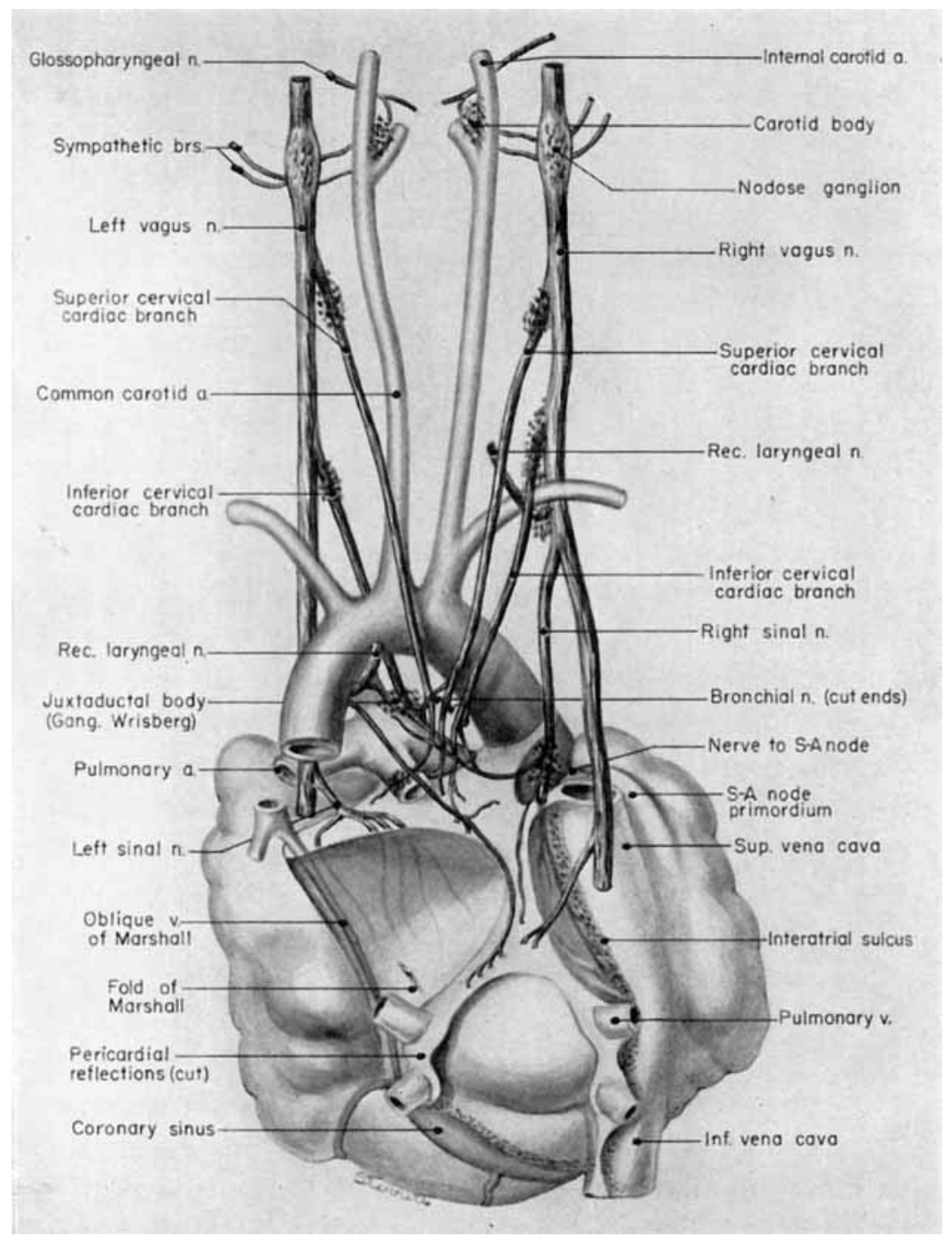

Fig. 15 Dorsal aspect of the heart of a $31.5-\mathrm{mm}$ embryo, showing the distribution of the cardiac nerves in relation to the pericardial reflections and the locations of the cardiac ganglia. (Reconstruction $\times 100$, illustration $\times 50$.) 
By the 9th week two major cardiac branches leave each vagus nerve at cervical levels (figs. 14, 15). These are the superior cervical and inferior cervical cardiac branches which together participate in the formation of the truncoconal plexus. The left superior cervical eardiac branch passes dorsal to the arch of the aorta, as is the case with both the superior and inferior cervical cardiac branches of the right vagus. These cardiac nerves converge dorsal to the great arterial trunks where they distribute parasympathetic fiber's principally to the ascending aorta, the primordium of the ganglion of Wrisberg, and the pulmonary trunk (figs. 14, 15). Some terminal filaments from this plexus enter the caval plica.

The inferior cervical cardiac branch of the left vagus passes ventral to the arch of the aorta. Within the subaortic recess, iust to the right of the ductus arteriosus and pulmonary trunk, it bears a mass of neuroblastic tissue (fig. 14) which is the primordium of the ganglion of Wrisberg (Wrisberg, 1783). Part of one of the probable pathways of migration of these cells is indicated by aggregations of histologically similar tissue strung out along the left vagus and its recurrent laryngeal branch. Before passing through this ganglionic condensation, the left inferior cervical cardiac branch gives off minute fibers which enter a nerve plexus in relation to the aortic arch and the ductus arteriosus. Nerve fibers and neuroblasts leave this mass to descend in the interval between ascending aorta and pulmonary trunk and terminate in a plexus in relation to the conus and the coronary arteries. Neuroblasts are strewn along the left inferior cervical cardiac branch and there is a particularly large mass associated with it as it passes ventral to the arch of the aorta. The right superior cardiac nerve contributes a comparable branch which passes ventrolaterally to the arch of the aorta and distributes fibers to the ascending aorta. Some smaller cardiac rami are contributed to the truncoconal plexus by the left recurrent laryngeal nerve together with rami from the right and left sinus nerves. 
Cardiac branches, which leave the vagi at thoracic levels, constitute the major contribution to the sino-atrial (deep) cardiac plexus. The main thoracic cardiac branch from the left ragus passes from the mediastinum to enter the fold of Marshall where it breaks up into several small rami. This nerve was originally the nerve to the left horn of the sinus venosus and for this reason it can be designated as the left sinal nerve (fig. 15), a term which is equally appropriate in the adult in view of the fact that its most lateral branch accompanies the oblique vein of Marshall. Some of its fibers reach the left pair of pulmonary veins by way of the left limb of the venous mesocardium. Others terminate in the heart wall at the point of mesocardial attachment. Still others extend as far as the coronary sinus where they come in relation with terminal ganglion cells.

A similar thoracic eardiac branch leaves the right vagus at a somewhat higher level. This right sinal nerve (fig. 15) originally distributed branches to the right horn of the sinus venosus, and now innervates the sinus venarum. Small rami from it pass through the venous mesocardium of this region and thus come into relation with the ganglion cells situated dorsally along the interatrial sulcus. Nerve fibers appear to penetrate the heart wall along this sulcus, reaching the interatrial septa and bases of the venous valves internally. A branch of the right sinal nerve courses within the adventitia of the superior vena cava to reach the right aspect of the primordium of the sino-atrial node which it penetrates (fig. 14). An additional branch from approximately the same level passes to the ganglion of Wrisberg and the left pulmonary artery. At lower thoracic levels a fairly stout cardiac branch enters the caval plica at its parietal pericardial attachment.

Sympathetic fibers accompany practically all the branches of the vagi and in some situations cannot be distinguished from them. Although their exact distribution at this age is not yet clearly established, three major cardiac branches leave the sympathetic ganglia at cervical levels. At thoracic levels the number and ultimate distribution of sympathetic cardiac 
nerve strands are obscure. The principal thoracic sympathetic cardiac branches accompany the left and right sinal nerves and have a similar distribution to the heart wall.

At this stage, migrating neuroblasts are strewn throughout practically the whole extent of both vagi and their branches. Local concentrations of them are intimately related to the great vessels. The locations of some of the major juxtavascular aggregations are shown in figure 14. A particularly prominent mass lies in the interval between the internal and external carotid arteries, immediately above the carotid sinus. This condensation, the primordium of the carotid body, lies characteristically within the adventitia of the internal carotid artery. At this level, the internal carotid lies close to the superior cervical ganglion and the nodose ganglion. Parasympathetic contributions to the developing carotid body come from the superior laryngeal branch of the vagus, as well as a relatively stout branch (nerve of Hering) from the glossopharyngeal nerve. Neuroblasts accompany these nerve fibers. Thus one component of the carotid body is derived from the original concentration of mesodermal cells lying within the adventitia of the internal carotid artery; the other is an invasion of neuroblasts.

There are two areas on the dorsal wall of the heart where concentrations of terminal ganglion cells may be found readily. One is along the interatrial sulcus, and the other is in the depression between the coronary sinus and the bulge in the left atrial wall caused by the entering pulmonary veins. From these two areas neuroblasts that have invaded the heart wall may be seen in abundance, deep in septum secundum, between the lower basal attachment of septum primum and that of the left venous valve. Beyond this region neuroblasts reach the primordium of the atrioventricular node and the His bundle. An aggregation of neuroblastic tissue is found at the point where the branch to the sino-atrial node leaves the main right sinal nerve (figs. 14, 15). Neuroblasts are distributed all along the course of this nerve, and ultimately pass through the mesocardium of the superior vena cava to reach the medial aspect 
of the sino-atrial node primordium. A few neuroblasts reach the dorsal wall of the superior vena cava, as well as the lateral aspect of the node. The dorsal wall of the inferior vena cava is rich in ganglion cells. Superficially, other scattered ganglion cells may be found within the epicardium, particularly along the courses of the coronary arteries and their branches.

\section{Conduction system}

The histological characteristics of the adult sinoventricular conduction system are not yet fully differentiated at the 9th week. Nevertheless, the primordia of the sino-atrial node and the atrioventricular (His) bundle are definitely recognizable. The node is foreshadowed by a fascicle of muscle fibers (fasciculus sino-atrialis), the main mass of which lies ventrolateral to the entrance of the superior vena cava into the right atrium (figs. 3,12). In section, this primordium is crescentic with its concavity adjacent to the ventral margin of the caval orifice (fig. $16 \mathrm{~B}$ ). The right limb, which is actually a direct continuation of the body of the primordium, swings laterally along the caval side of the sulcus terminalis whence it fans out dorsally in the sinus wall. Its fibers are oriented for the most part in a cephalocaudal direction in the dorsal wall of the sinus. They are fusiform and have elongated nuclei.

The fibers within the main mass of the sino-atrial node have a less consistent orientation than those in its right limb. An ill-defined group of fibers leaves the primordium on its medial aspect and passes dorsomedially to terminate near the cone of origin of the right pair of pulmonary veins. These fibers constitute the left limb of the node (fig. 12). Although they stain less intensely than the remainder of the primordium, they nevertheless show clear transverse striations. This left limb may be identified in the adult heart as part of an interatrial band of muscle which has been described under various names by several authors - Keith and Flack ('06, '07), Tandler ('12), Lewis, Meakins and White ('14), Bachmann ('16), and Papez ('20). 

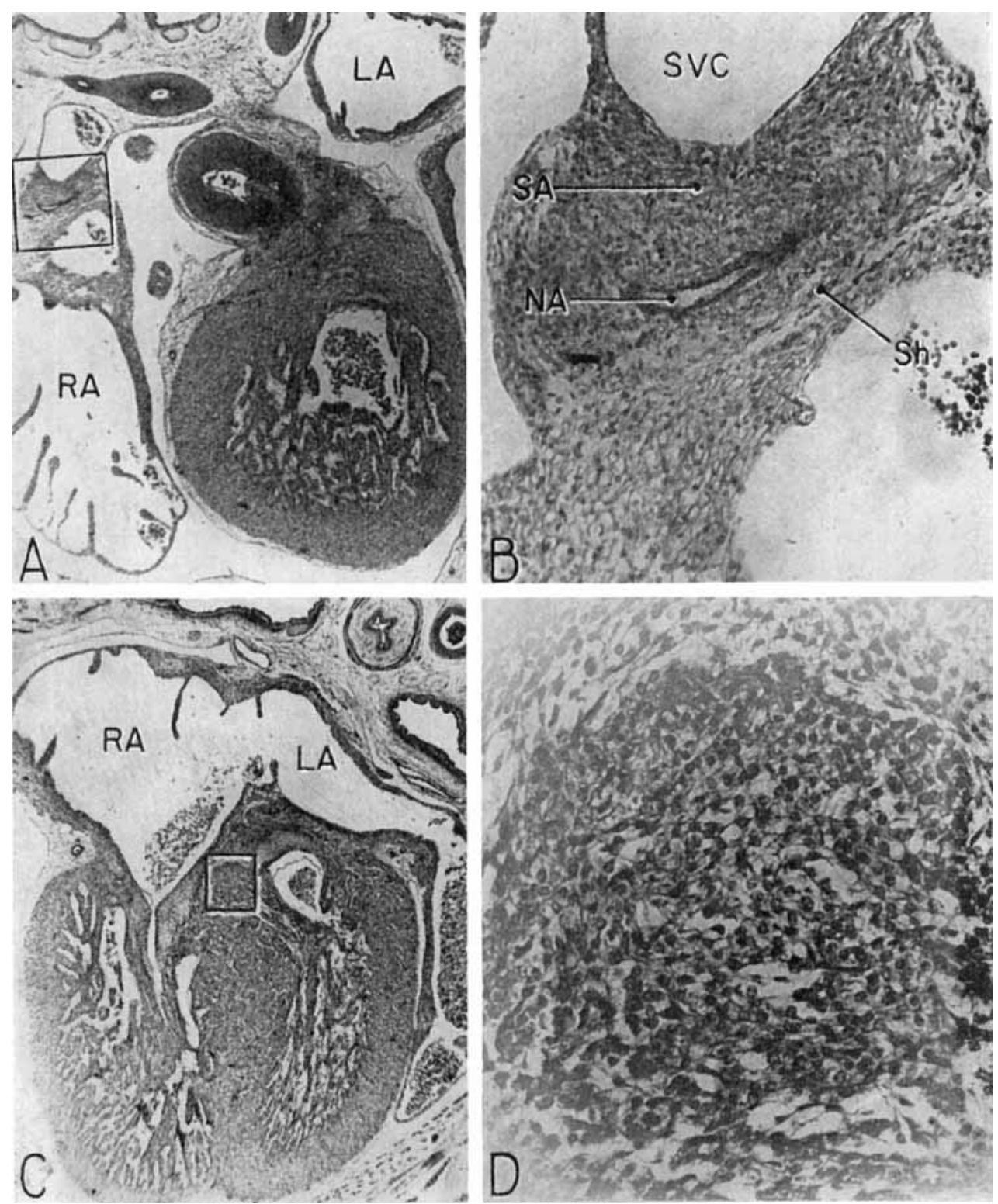

Fig. 16 Photomicrographs showing parts of the developing sinoventricular conduction system in the heart of a $31.5-\mathrm{mm}$ embryo.

A. Section $(\times 27)$ passing through right atrium near level of entrance of superior vena eava. Abbreviations: LA, left atrium; RA, right atrium.

B. Area indicated by rectangle in A, photographed at higher magnification $(\times 125)$ to show the primordium of the sino-atrial node. Note the position of the nodal artery. Abbreviations: NA, nodal artery; SA, sino-atrial node; Sh, connective-tissue sheath; SVC, superior rena cara.

C. Section $(\times 20)$ through the interventricular septum from same heart as that sliown in A. LA, left atrium; RA, right atrium.

D. Area indicated by rectangle in $\mathrm{C}(\times 208)$ to show the main conduction bundle of His. 
The tissue of the nodal primordium as a whole takes a deeper stain than the less compact atrial myocardium outside this specialized area. Throughout practically its entire extent, the muscle fibers of the sino-atrial primordium are in syncytial continuity with those of the adjacent atrial myocardium. A delicate, loosely organized embryonic connective tissue sheath presents only a vague demarcation between the nodal primordium and the remainder of the myocardium.

In contrast with the clearly recognizable sino-atrial node, I was unable to find any clearly established primordium representing the atrioventricular node in either of the hearts reconstructed.

The ventricular component of the conduction system is more distinct, histologically, from the rest of the myocardium than is the atrial component. The primordium of the atrioventricular (His) bundle is recognizable as a band lying along the crest of the interventricular septum musculare (fig. 13). It skirts the right inferior margin of the centrally located, composite mass of endocardial cushion tissue which will form the septum membranaceum. The flange which is the primordium of the septal (medial) cusp of the tricuspid valve has its origin immediately cephalic to the bundle. The histological characteristics which, at this age, distinguish the His bundle from the ventricular myocardium are the more compact arrangement of its fibers and the deeper staining of its nuclei (figs. $16 \mathrm{C}, \mathrm{D}$ ). Its fibers merge with the adjacent myocardium without any definite line of demarcation. Their nuclei are large, elongated, and deeply staining. Faint transverse striations can be seen in the branches of the bundle, but they cannot be made out as readily in the bundle itself. The bundle is beginning to be separated from adjacent tissues by a delicate sheath of young connective tissue in which a homogeneous mucoid substance occupies the interstitial spaces.

Among the first branches to leave the main bundle for the right ventricle are small fascicles extending into the more dorsal parts of the ventricular wall. These are the dextrodorsal branches (fig. 13). Other small twigs (dextrovalvular 
branches) extend into the muscle lamina which, at this stage, lies along the ventricular face of the septal (medial) cusp of the tricuspid valve (fig. 13). Beyond these twigs the major part of the right branch courses along the septum to pass finally into a short, stout trabecula which is the primordium of the moderator band (trabecula septomarginalis Leonardii). Fine fibers extend from this band into the anterior papillary muscle and spread out into the myocardium. The right branch, together with its offshoots, constitutes the dextroventral component of the ventricular conduction system.

The left branch leaves the main bundle just below the point where the septal (anterior) cusp of the mitral valve attaches to the interventricular plug of endocardial cushion tissue. It gives off small fascicles to dorsal parts of the ventricular wall, the so-called sinistrodorsal branches (fig. 13). Other filaments (sinistrovalvular branches) from the bundle extend into the myocardium along the ventricular face of the mitral valve. Although the general histological characteristics of the left branch are similar to those of the right, it has a more diffuse distribution. Rami from the left branch extend into the wall of the subaortic sinus, the adjacent trabeculae, and along the left face of the muscular interventricular septum. These branches constitute, collectively, the sinistroventral component of the ventricular part of the conduction system. The delicate fascicles of this component lie immediately under an extremely thin endocardium, which appears to consist in some areas solely of endothelium.

The muscle fibers in the region of the atrioventricular junetion were found to be in a definite state of atrophy, with the enlarged interstitial spaces occupied by a homogeneous gelatinous substance. The endocardial cushion tissue of this region appeared to be generally more richly cellular, and fibroblasts from this tissue had apparently already begun to invade the interstices between the atrophic muscle fibers. This was particularly true of the "interventricular plug" and was interpreted as being part of an early phase in the formation of 
9 weeks the separation of the originally continuous atrial and ventricular myocardium is well advanced. The only nonregressing atrioventricular muscular connection is the atrioventricular bundle already described.

ISISCUSSION

The septal system

The major morphological features of the heart at the beginning of the third month should be considered in the light of earier and later stages. Characteristically, there exists at each phase a balanced interplay between the inherent developmental processes which mould the various cardiac structures and the hemodynamies of the intracardiac circulation. This aspect of cardiogenesis, particularly for the late fetal period, has received considerable attention. Conspicuous among the controversial issues has been the question of the complete crossing of caval currents in the right atrium, a tenacious doctrine originally postulated by Sabatier in 1791. In this connection Pohlman ('07, '09), by the injection of colored starch grains, and Kellogg ('28, '30), by oxygen analyses, demonstrated that the inferior caval blood stream does not pass entirely through the interatrial foramen. An evaluation of this concept with regard to the human heart was made by Patten, Sommerfield and Paff ('29) on the basis of the sizes of the significant cardiac apertures in fetuses at term. They showed that the narrowest part of the interatrial channel is the opening into the left atrium between the free edge of septum primum and that of the septum secundum. This they designated as the "functional orifice." Their studies indicated that the functional orifice of the foramen ovale was not sufficiently large to accommodate all of the inferior caval blood and that, as a result, a partial mixing of caval blood streams must be presumed to occur within the right atrium. This conclusion is strengthened by the recent work of Barclay, Franklin and Prichard ('44) who demonstrated, br means of cineradiographic techniques, that in the fetal lamb 
by no means all of the inferior caval stream passes directly into the left atrium. In spite of the extensive work on this problem by various investigators, there still exists some lack of agreement as to the precise details of the intracardiac circulation in the human fetus, although the divergence of opinion among competent observers is lessening as new bits of evidence are brought to bear.

In the 9 th week the relations in the cardiac territory where the great veins open into the sinal bay of the right atrium differ essentially from those of a fetus near term. The interatrial communication is relatively larger, and the sinal bay of the right atrium much deeper. The venae cavae, as well as the coronary sinus, open into this deep bay making it the common entrance for the venous blood from systemic, portal, and placental circulations. In contrast to this tremendous intake in the right atrium, the pulmonary return to the left atrium is still relatively small. Nevertheless, from the capaciousness of the left atrial chamber one can reasonably deduce that it must receive a proportionate volume of blood. As a matter of fact, the two atria are approximately equal in size indicating that they accommodate reasonably comparable amounts of blood. There must be, therefore, a relatively large quantity of blood which enters the left atrium by way of the foramen ovale, thereby making for equalized intakes. As has already been pointed out, the morphology of the interatrial septal complex, at this stage, is fully in line with such a concept.

From the confined nature of the sinal bay due to a highly developed right venous valve, it seems probable that there must oceur within it some mixing of blood from the superior cava and coronary sinus with that part of the inferior caval stream that does not enter the left atrium. The inferior vena cava, however, is so oriented that its stream is directed essentially toward the foramen ovale so it is undoubtedly the dominant source of the equalizing flow to the left atrium. A further analysis of this orientation, in hearts of 9 weeks, shows that the stream of hlood from the inferior vena cava 
must impinge on the ventral pillar of septum secundum (limbus foraminis ovalis) and is probably divided into two streams as postulated by Franklin and his co-workers for the lamb heart at term. Because of the splitting of the inferior caval current Franklin designates this margin of septum secundum as the crista dividens, and refers to the path taken by the divided stream to the left, through the foramen ovale, as the via sinistra. In like manner he names that path taken by the part of the caval stream directed toward the right atrium, the via dextra.

The area of the interatrial functional orifice in the 9 th week is roughly equal to the inferior caval inlet. This is in striking contrast to conditions at term when, as shown by Patten, Sommerfield and Paff ('29), the functional orifice of the interatrial channel is only about $40 \%$ of the orifice of the inferior vena cava. The relative diminution in the size of the interatrial communication as development progresses is, as Patten et al. emphasized, correlated with the increasing pulmonary return to the left atrium as the lungs begin their rapid development in the latter part of pregnancy.

In 1669 Lower described a local elevation situated in the dorsal wall of the sinus venarum, and stated that its function was to divert the flow from the superior vena cava into the right atrium and thus prevent it from hindering the inflow from the inferior vena cava. Recently Franklin has renamed this elevation, which is conspicuously present in the fetal sheep heart, calling it the crista interveniens. In the past, this structure has commonly been termed the tubercle, or torus, of Lower. In the human heart, though recognizable, it is less distinct than in the sheep. At the 9th week, the crista interveniens is represented by a ridge arising, in part at least, as a result of an angulation of the dorsal wall of the sinus venosus due to the underlying right pair of pulmonary veins. This angulation is certainly in a position lending plausibility to the contention that it may direct some of the superior caval blood away from the foramen ovale, al- 
though a partial mixing of the two caval streams within the confined sinal bay seems inevitable.

The comparatively high degree of development exhibited by the right venous valve during the middle trimester of pregnancy, has received considerable attention. Born (1889) held that the sinus valves develop in situ. Röse (1889), on the other hand, asserted that during development the sinus and atrial walls became apposed for some distance along their zone of union, thus adding to the extent of the venous valves by a sort of infolding process. Waterston ('18), also, described the "invagination" of the right horn of the sinus venosus into the atrium as giving rise to the sinus valves. Odgers ('35) was in partial agreement when he maintained that "co-aptation" of the sinus wall with that of the atrium gives rise to the right venous valve, but not the left. In the present study evidence in support of this "infolding" process was found only in those parts of the venous valves near the inlets of the cavae. At these levels, the right venous valve in particular contained a central sheet of delicate embryonic connective tissue which could be interpreted as a carrying-in of the epicardium.

The ultimate fate of the right venous valve has long been known to be significant in the origin of the filamentous or reticulate structures which are found in the right atrium of some adult hearts. A great variety of such vestiges are generally referred to as Chiari's nets. The present study indicates that a Chiari's net could result from less than the normal amount of resorption of the venous valves, principally the right valve, and the associated septum spurium. When, as occasionally happens, the resorption is incomplete there are bound to be net-like remnants bordering the old sinal bay.

The atrioventricular junction is a clearly defined, modified area of the heart wall. Attention has already been drawn to the fact that this junction is marked, internally, by endocardial cushion tissue which plays an important role in the formation of the cardiac skeleton. In embryos of the 9th week, the primordium of the septum membranaceum of the adult 
heart is represented by a composite mass of endocardial cushion tissue (Odgers, '38; Kramer, '42) situated just above the primary muscular part of the interventricular septum. This mass is what His (1885) called the septum intermedium. The thinning of this interventricular plug during later stages gives rise to the septum membanaceum of the adult heart. As a result of subsequent changes of the position of the septal cusp of the tricuspid valve, the septum membranaceum becomes divided into atrioventricular and interventricular components. The manner in which these changes are accomplished has not yet been worked out in detail, although differential growth and redistribution of the endocardial cushion tissue appear to be important factors in the process.

\section{Coronary circulation}

The rapidity with which the coronary circulation is established is one of the striking features of cardiac development. The markedly developed right nodal artery at 9 weeks (fig. 12 ) is in keeping with the presence, at this stage, of a welldefined primordium of the sino-atrial node. The homologous left nodal artery, when present, may develop even earlier than the right. In many instances, by the 9 th week, this vessel appears to have passed the peak of its relative development and begun to undergo atrophic changes. When present it takes its origin from a point in front of the oblique vein of Marshall (left common cardinal vein) which corresponds, on the left side, to the position of the sino-atrial node on the right. Its association with this regressing vessel may underlie the fact that a left sino-atrial artery tends to undergo atrophic changes developmentally and is, therefore, the less frequent source of the blood supply for the sino-atrial node in the adult.

The ramus septi fibrosi, which is the chief source of the blood supply for the atrioventricular node in the adult, is recognizable although relatively poorly developed at this stage (fig. 13). This is in consonance with the fact that in the 9th 
week the primordium of the atrioventricular node is poorly defined. The ramus septi fibrosi was the only blood vessel which could be found penetrating the atrioventricular junction at this age. The principal blood supply to the right branch of the bundle of His is by means of a branch of the left conal artery (fig. 13). The right conal artery has a less extensive distribution.

\section{Innervation}

The basic plan of cardiac innervation can be more readily understood from the pattern established in the 9-week embryo than from the complex plexuses present in the adult. In embryos of this age the cardiac branches of the vagus nerve are more fully developed and more easily distinguishable than those of the sympathetic trunk. The sympathetic branches, however, could be identified accompanying those of the vagus to reach the heart wall at the same relative points. In some situations it was not possible to distinguish clearly between the two as they converged on the heart. It was for this reason that the compound term "vagosympathetic" was suggested as a name for these particular fibers by Keng (1893).

The manner in which a branch of the left sinal nerve of the sino-atrial plexus accompanies the oblique vein of Marshall (fig. 15) is of particular interest. In the adult, Worobiew ('28) described the part of the fold of Marshall which transmits this nerve as the "plica nervina atrii sinistri." Perman ('24) deseribed a similar nerve passing through the "Marschallsche Perikardialfalte." In this same paper he acknowledged that Scarpa (1794) was the first to observe it in man, and stated that Schumacher ('02) noted it in only two cases out of 30 examined. Perman, nevertheless, considered this nerve to be constant for man. This nerve is designated here as the left sinal nerve (fig. 15). It should be recognized that, although it consists primarily of parasympathetic fibers at this stage, sympathetic components probably already accompany it. Its homologue, the right sinal nerve, is better developed and its distribution is easier to follow. 
The sinal nerves are undoubtedly derivatives of the nerves that Shaner ('30), in his study of younger developmental stages of the pig heart, called the "left and right cardinal nerves." In adult man it seems preferable to designate the left sinal nerve as the nerve to the coronary sinus and the right sinal nerve as the nerve to the sinus venarum.

The primordium of the atrioventricular node appears to receive contributions from both right and left vagus nerves. This is in sharp contrast with the fact that the primordium of the sino-atrial node receives only a specific branch from the right sinal nerve.

In the present work an attempt was made to determine, also, the distribution of neuroblasts over the surface of the heart. Many aggregations of such terminal ganglion cells were found in relation to the great vessels and the base of the heart. Those in relation to the blood vessels can conveniently be designated as juxtavascular bodies. One of these masses of tissue, namely the carotid body, contained epithelioid cells as well as neuroblasts. For this reason the inclusion of this composite tissue by various authors (Wiesel and Biedel, '02; Trinci, '07; Bussachi, '12 ; Rabl, '22 ; Watzka, '30 ; Penitschka, '31; Palme, '34; Seto, '35; Muratori, '34; and Nonidez, '35, '39) under the general heading of "paraganglia" is misleading in that it connotes that all of this tissue is derived exclusively from neural crest ectoderm. DeCastro ('26) and Boyd ('37) asserted that the primordium of the carotid body is predominantly mesodermal in origin.

A mass of neuroblastic tissue arises in relation to the ductus arteriosus. In this paper this tissue is designated as the juxtaductal body (fig. 14). The close relationship of this mass to the ductus would suggest that it may be concerned in regulating its caliber. The ganglion of Wrisberg (1793) is derived from this primordium and retains a similar relationship to the ligamentum arteriosum. The function of this ganglionic mass in the adult is uncertain.

The neuroblastic mass directly related to the nerve of the sino-atrial node is found at the point where this nerve leaves 
the main right sinal nerve (figs. 14, 15). A few terminal neuroblasts lie within the nodal primordium itself. The innervation of the atrioventricular node is less specific. Belowa ('28) described a $\cdot$ depression of the dorsal cardiac wall, situated medial to the inferior caval orifice and cephalic to the atrioventricular junction. He designated this depression as the "Fossula cordis nervina," emphasizing its rich innervation. In the 9 th week there is no depression since this area is filled by a thick mass of embryonic epicardial connective tissue. It should be noted, however, that the area in question is the place at which the nerves and blood vessels to the primordium of the atrioventricular node penetrate the heart wall.

\section{Conduction system}

The discovery of specialized muscle fibers by Purkinje ${ }^{2}$ early in the 19th century opened the door for a series of studies on the coordination of contraction in the mammalian heart. Stanley Kent (1893) and Wilhelm His, Jr. (1893) almost simultaneously announced the discovery of a muscular connection between atrium and ventricle. The presence of the atrioventricular bundle was subsequently substantiated by the work of Braeunig ('04), DeWitt ('09) and Lewis ('17). Tawara published his discovery of the atrioventricular node in 1906. In 1907 Wenckebach described as the site of initiation of the impulse to contraction a fascicle of muscle (Schlingenfasern) arising in the proximal part of the superior vena cava. In the same year Sir Arthur Keith, with the collaboration of Martin Flack, described the sino-atrial node which they presumed to be the site of origin for the impulse of heart contraction. This concept was proved to be correct by the extensive electrocardiographic investigations of Sir Thomas Lewis beginning in 1910.

${ }^{2}$ Bibliographically, Purkinje is acknowledged as having discovered the modified cardiac muscle fibers, which bear his name, in 1845. This work was, however, first reported in 1839 by Bogislaus Palicki, one of Purkinje's students, in lis published treatise, "De musculari cordis structura," Breslau, in Volume 24 of Medical Dissertations, 40 pages, Dec. 1839, giving full eredit to Purkinje for the original discovery. 
Relatively recently, the developmental aspects of the propagation of the heart beat have attracted a wide interest (Retzer, '20; Shaner, '29 ; Patten and Kramer, '33; Hoff, Kramer, DuBois and Patten, '30; Goss, '40, '42; Walls, '47 ; and Patten, '49).

An understanding of the histogenesis of the junctional region of the atria and ventricles is necessary as a basis for understanding the development of a specialized atrioventricular conduction system. In the 9 th week the atria are still incompletely separated from the ventricles at the atrioventricular junction although the formation of the fibrous annulus has been presaged by connective tissue invasion and the muscle fibers have undergone partial atrophy. There is apparently some individual variability in the completeness with which atrial and ventricular muscle are finally separated by this process. In this regard, Kent (1893) remarked: "It would appear then that the fact of two masses of muscle being joined together by fibrous tissue is in itself no argument against the muscular continuity of such masses, the fibrous nature of the intervening tissue by no means excluding the possibility of muscular fibers running through it and preserving the muscular connection." We now know of course that some of the original myocardial continuity may be retained in the adult heart in the form of accessory bundles giving rise to variations in conduction phenomena (Wolff, Parkinson and White, '30).

The most strongly developed component of the sinoventricular conduction system in the 9-week heart is the main atrioventricular bundle which courses along the crest of the interventricular septum musculare. Even in this location the bundle is not completely separated from the muscular part of the interventricular septum by its developing connective tissue sheath. There is at this age considerable continuity between the main bundle and the adjacent cardiac muscle of the septum. Apparently some of this continuity is normally retained in the adult. The function of "para-specific septal conduc- 
tion" has been attributed to such fibers in the adult heart by Mahaim and Winston ('41).

The sinistrodorsal and sinistrovalvular branches of the conduction system of the embryo (fig. 13) probably give rise to the fascicles described in the adult heart by Mahaim ('32) as the "... connexions superieures et posterieures de la branche gauche. . ' The dark-staining quality of the conduction tissue, at this age, contrasts sharply with the paler staining qualities (Mahaim, '31) of the same tissue in the adult heart. Terminal fibers, similar to the Purkinje fibers characteristic of the adult heart, do not appear to be recognizably differentiated in hearts of the 9 th week.

\section{SUMMARY ANI) CONCLUSIONS}

This study of the morphology of the human heart in the 9 th week of development was based primarily on wax-plate reconstructions augmented by transparent plastic reconstructions of certain regions. Microdissections of embryos in this age period were made for cardiac relations and proportions. This stage was selected because most of the cardiac structures recognized in the adult are already clearly established and yet are still sufficiently embryonic to reflect the developmental processes involved in their origin.

The interatrial septal complex is of particular interest. There has been extensive resorption of septum primum to form a large ostium secundum. A thick, but not yet fully developed, septum secundum delimits a wide foramen ovale. This arrangement leaves a much freer interatrial communication than is characteristic of the heart at term.

The right venous valve is extraordinarily highly developed at this age, whereas the left venous valve already has been considerably reduced. As a result there is a deep sinal bay of the right atrium between the right venous valve and the interatrial septal complex into which all the major veins empty. The morphology of this region suggests that a considerable part of the inferior caval blood stream passes directly through 
the interatrial "functional orifice" into the left atrium. The right venous valve may well act as a baffle helping to insure adequate charging of the left atrium which still has only a relatively small direct return from the lungs. In the sinal bay there must be considerable mixing of the blood entering by way of the superior vena cava and the coronary sinus with that part of the inferior caval blood that does not go to the left atrium.

The septum membranaceum is not, as yet, fully differentiated histologically, but the interventricular foramen has been closed by a composite mass of endocardial cushion tissue lying along the crest of the interventricular septum musculare. Some of this tissue extends into the primordia of the atrioventricular valves as part of their framework. The framework of the valves at this stage is two-layered. Beneath the atrial endothelium it is composed of endocardial cushion tissue; under the ventricular endothelium there is still a layer of cardiac muscle. The endocardial cushion tissue of this region, together with that lining the atrioventricular orifices, will participate in the formation of the fibrous skeleton of the heart.

By the 9th week all of the major cardiac vessels are present and there are already special branches to the sino-atrial node and to the main atrioventricular bundle.

Both divisions of the autonomic supply are represented in the 9-week heart, but the parasympathetic branches from the vagus are more highly developed than the sympathetic branches. Local aggregations of neuroblasts are found in many areas in relation to the heart and the great vessels.

A well-defined primordium of the sino-atrial node can be identified by the 9 th week. The bundle of His, and its major branches, is the most strongly developed component of the conduction system at this age. The atrioventricular node was not clearly recognizable and the terminal (Purkinje) fibers were as yet undifferentiated from the rest of the cardiac muscle fibers. 


\section{ACKNOWLEDGMENT}

My deepest appreciation and thanks are due to Dr. Bradley M. Patten who suggested this study and who has given generously of his time for consultation throughout its progress. I would, also, like to thank Dr. Alexander Barry who has offered many constructive suggestions, and Dr. Theodore C. Kramer on whose technical skill and knowledge of heart development I have drawn freely.

\section{JITERATURE CITED}

Bachmann, G. 1916 The interauricular time interval. Am. J. Plysiol., 41: $309-320$.

Barclay, F. P., K. J. Franklin and M. L. Prichard 1944 The Foetal Circulation. Charles C Thomas, Springfield, Ill., xvi $+275 \mathrm{pp}$.

Barcroft, J. 1947 Researehes on Prenatal Life. Charles $C$ Thomas, Springfield, Ill., xiii $+292 \mathrm{pp}$.

Belowa, M. 1928 Fossula cordis nervina. Zeitsehr. f. Anat. u. Entwg., $86: 517-$ 531.

BorN, G. 1883 Die Plattenmodellirmethode. Arch. f. mikr. Anat., 22: 584599.

1888 Über die Bildung der Klappen, Ostien und Scheidewände in Säugetierherzen. Anat. Anz., III Jahrg., 3: 606-612.

1889 Beiträge zur Entwicklungsgesehichte des Säugethierherzens. Areh. f. mikr. Anat., 44: 284-378.

Boyn, J. D. 1937 The development of the human earotid body. Contrib. to Embryol., Carnegie Inst. of Washington, 26:3-31.

BRAEUNiG, K. 1904 Ueber musculöse Verbindungen zwischen Vorkammer und Kammer bei versehiedene Wirbelthierherzen. Areh. f. Anat. u. Playsiol., (physiol. Abth. suppl. Bd.), pp. 1-19.

Bussachi, P. 1912 I corpi cromafini del cuore umano. Arch. Ital. di Anat., 11: $352-376$.

Chiari, H. 1897 Ueber Netzbildungen im rechten Vorhofe des Herzens. Beitr. z. path. Anat. u. z. allg. Path., 22: 1-10.

Cruvemhiner, J. 1849 Traite d'Anatomie Descriptive. 2nd ed., Labé, Paris, $620 \mathrm{pp}$.

Davis, C. L. 1925 The primary divisions of the myocardium in the human embryo. Anat. Rec., 29: 355 .

1927 Development of the human heart from its first appearance to the stage found in embryos of 20 paired somites. Contrib. to Embryol., Carnegie Inst. of Washington, 19: 245-284.

DeCastro, F. 1926 Sur la strueture et I'innervation de la glande interearotidienne (glomus caroticum). Trav. du Lab. de Recherches biol, de l'Univ. Madrid, 24: 365-373. 
DEWITT, L. M. 1909 Observations on the sino-ventricular connecting system of the mammalian heart. Anat. Rec., s: 475-497.

Franklin, K. J. 1948 Cardiovascular Studies. Charles C Thomas, Springfield, Ill., xvi + 306 pp.

Gerauder, E. 1928 Le mechanisme du coeur des anomalies. Arch. Mal. Coeur., 21: 148-151.

Goss, C. M. 1940 First contractions of the heart without cytological differentiation. Anat. Rec., $76: 19-27$.

1942 The physiology of the embryonic mammalian heart before circulation. Am. J. Physiol., 137: 146-152.

Gross, L. 1921 The Blood Supply to the Heart. Paul B. Hoeber, New York, $\mathrm{xri}+171 \mathrm{pp}$.

HaAs, G. 1911 Über die Gefässversorgung der Reizleitungssystems des Herzens. Inaug. Diss., Freiburg. (Also in Anat. Hefte, Bd. 43, pp. 627-658.)

Haller, A. 1786 First Lines of Physiology. Translated by W. Cullen. Troy O. Penniman and Co., Edinburgh, $498 \mathrm{pp}$.

Hrs, W. 1885 Anatomie menschlicher Embryonen. III. Zur Geschichte der Organe das Herz. F. C. W. Vogel, Leipzig, 3: 129-178.

1886 Beiträge zur Anatomie des menschlichen Herzens. F. C. W. Vogel, Leipzig, $6: 251-273$.

HIs, W., JR. 1891 Die Entwickelung des Herznervenssystems bei Wirbelthieren. Abhand. math, phys. Klasse der König. Säch. Ges. d. Wiss., 18: 1-64.

1893 Die Thätigkeit des embryonalen Herzens und deren Bedeutung für die Lehre von der Herzbewegung beim Erwachsenen. Arbeiten aus der med. Klinik zu Leipzig, pp. 14-50.

1897 Über die Entwjekelung des Bauchsympathikus beim Hühnehen und Menschen. Arch. f. Anat. u. Entwg., suppl., 137-170.

Hoff, E. C., T. C. Kramer, D. DuBois aNd B. M. PatTen 1939 The development of the electrocardiogram of the embryonic heart. Am. Heart J., $17: 470-488$.

Kastschenko, N. 1886 Methode zur genauen Reconstruktion kleinerer mikroskopischer Gegenstände. Arch. f. Anat. u. Entwg. (His. u. Braune Jahrg.), $5: 388-394$.

KeIth, A., ANd M. FLACK 1906 The auriculo-ventricular bundle of the human heart. Lancet, 2 : 359-364.

1907 The form and nature of the muscular connections between the primary divisions of the vertebrate heart. J. Anat. and Physiol., 2 : $172-189$.

KfllogG, H. B. 1928 The course of the blood through the fetal mammalian heart. Anat. Ree., $42: 443-465$.

1930 Studies on the fetal circulation of mammals. Am. J. Physiol., $91: 637-648$.

Keng, L. B. 1893 On the nervous supply of the dog's heart. J. Physiol., 14: $467-482$.

KENT, A. F. S. 1893 Researches on the structure and function of the mammalian heart. J. Physiol., 14: 233-254. 
KENT, A. F. S. 1913 The structure of the cardiac tissues at the auriculoventricular junetion. J. Physiol., $47:$ 17-19.

1914 A conducting path between the right auricle and the external wall of the right ventricle in the heart of a mammal. J. Physiol., 48: XXII-XXIV.

KRAMER, T. C. 1942 The partitioning of the truncus and conus and the formation of the membranous portion of the interventricular septum in the human heart. Am. J. Anat., 71: 343-370.

LEwIs, T. 1910 The pacemaker of the mammalian heart, as ascertained by electrocardiographic curves. J. Physiol., 41: ix-x.

Lewis, T., J. Meakins and P. White 1914 The excitatory process in the dog's heart. Phil. Trans. Roy. Soc. of London, 205: 375-420.

1917 Upon the motion of the mammalian heart. Proc. Roy. Soc. London, 89: 560-573.

Lower, R. 1669 Tractatus de Corde. Item de Motu and Colore sanguinis et Chyli in eum Transitu. (Cited from K. J. Franklin, '32, Facsimile Ed., with introduction and translation of R. Lower's: 'Tractatus de Corde,' ete., Gunther's 'Early Seience in Oxford,' Vol. 9, London.)

Mahalm, I. 1931 Les Maladies organiques du Faisceau de His-Tawara. Masson, Paris, 551 pp.

1932 Nouvelles recherches sur les lesions du faisceau de His-Tawara. (Premier mémoire.) Le bloc bilateral manque nouvelle fourme anatomique de bloc du coeur à substituer au bloc dit " $\mathrm{d}$ 'arborisations." Ann. de Med., 3Q: 347-377.

Mafaim, I., and M. R. Winston 1941 Recherches d'anatomie comparée et de Pathologie éxperimentale sur les connexions haut du faiseau de His-

Tawara. Cardiologia, 5: 189-260.

MaLl, F. P. 1912 On the development of the human heart. Am. J. Anat., 13: 249-298.

1918 On the age of human embryos. Am. J. Anat., 23: $397-422$.

Marshall, J. 1850 On the development of the great anterior veins in man and mammalia; including an account of certain remnants of foetal structure found in the adult, a comparative view of these great veins in the different mammalia, and an analysis of their occasional peculiarities in the human subject. Phil. Trans., Pt. 1, pp. 133-170.

Moenkeberg, J. G. 1908 Untersuchungen über das atrioventrikular Bündel im mensehlichen Herzen. Gustav Fischer, Jena, 329 pp.

Muratori, G. 1934 Zona recettrice aortica e tessuto paragangliare. Boll. d. Soc. Ital. di Biol. Sper., 9: 1041-1044.

Nonidfz, J. F. 1935 The aortic (depressor) nerve and its associated epithelioid body, the glomus aorticum. Am. J. Anat., 57: 259-301.

1.939 Studies on the innervation of the heart. Am. J. Anat., 65: 361-413.

OdGERs, P. N. B. 1935 The formation of the renous valves, the foramen secundum and the septum secundum in the human heart. J. Anat., 69:412-422. 1938 The development of the pars membranacea septi in the human heart. J. Anat., rg: 247-259. 
Palme, F. 1934 Die Paraganglien über dem Herzen und in Endigungsgebiet des Nervus depressor. Zeitschr. f. mikr. anat. Forsch., $36: 391-420$.

PAPEZ, J. W. 1920 Heart musculature of the atria. Am. J. Anat., 27: 255-285.

PATTEN, B. M. 1930 The ehanges in circulation following birth. Am. Heart J., $6: 192-205$.

1931 The closure of the foramen ovale. Am. J. Anat., 48: 19-44. 1938 Developmental defects at the foramen ovale. Am. J. Path., $14: 135-162$.

1946 Human Embryology. The Blakiston Co., Philadelphia, 1st Ed., $x v+776$ pp.

1949 Initiation and early changes in the character of the heart beat in vertebrate embryos. Pliysiol. Rev., 29: 31-47.

1953 The Development of the Heart. Gould, "The Pathology of the Heart.", Charles C Thomas, Springfield, Ill., Chap. II, pp. 20-86.

Patten, B. M., AND T. C. Kramer 1933 The initiation of contraction in the embryonic ehick heart. Am. J. Anat., 53: 349-375.

Patten, B. M., A. Sommerfield and G. H. Paff 1929 Functional limitations of the foramen ovale in the human foetal heart. Anat. Ree., 44: 165178.

Penitschis, W. 1931 Paraganglion aorticum supracardiale. Zeitschr. f. mikr. anat. Forsch., 24: 24-37.

Perman, E. 1924 Anatomische Untersuchungen über die Herznerven bei den höheren Säugetieren und beim Mensehen. Zeitschr. f. Anat. u. Entwg., 71: $382-457$.

Pohlman, A. G. 1907 The fetal eirculation through the lieart. A review of the more important theories, together with a preliminary report on personal findings. Johns Hopkins Hosp. Bull., 18: 409-412.

1909 The course of the blood through the heart of the fetal mamnal, with a note on the reptilian and amphibian circulations. Anat. Rec., 3: 75-109.

Prrkinje, J. 1845 Mikroskopische neurologisehe Beobachtungen. Arch. f. Anat. u. Physiol., pp. 281-295.

RABL, H. 1922 Die Entwicklung der Carotisdrüse beim Mee"schweinchen. Arch. f. mikr. Anat., $96: 315-339$.

Retzer, R. 1920 The sino-ventricular bundle. A functional interpretation of morphological findings. Contrib. to Embryol., Carnegie Inst. of Washington, $9: 145-156$.

Rokitansky, K. F. 1875 Die Defecte der Scheidewande des Herzens. Path.anat. Abhandl., 156 pp. Wilhelm Braumüller, Wien.

Röse, C. 1889 Zur Fntwicklungsgeschichte des Säugethierherzens. Morph. Jahrb., 15: 436-456.

Sabatier, R. B. 1791 Traite complet d'anatomie, ou description de toutes les parties du corps humain. Mem. Acad. Roy. Sci., Paris, 2: 385-398.

SCARPA, A. 1794 Tabulae neurologicae ad illustrandum historiam anatomicam cardiacorum nervorum, noni nervorum cerebri, glossopharyngaei et pharyngaei ex octavo cerebri. Ticini, apud. B. Comini, pp. 1-44. 
Schumacher, S. 1902 Die Herznerven der Säugetiere und des Menschen. Sitzungsber. d. König. Akad. d. Wiss., Wien, Matem. naturw. Klasse, 111: 133-235.

SEro, H. 1935 Ueber zwischen Aorta und Arteria pulmonalis gelegene Herzparaganglien. Zeitschr. f. Zellforsch. u. mikr. Anat., 2Q: 213-231.

Shaner, R. F. 1929 The development of the atrioventricular node, bundle of His, and sino-atrial node in the calf, with a description of a third embryonic node-like structure. Anat. Rec., 44 : 85-99.

1930 On the development of the nerves to the mammalian heart. Anat. Ree., $46: 23-39$.

Strasser, H. 1887 Ueber die Methoden der plastischen Rekonstruction. Zeitschr. f. wiss. Mikr., 4: 168-205.

Streeter, G. L. 1951 Developmental horizons in human embryos: XI to XIII. Carnegie Institution of Washington, Washington, D.C., 2: $196 \mathrm{pp}$.

Tandere, J. 1912 The development of the heart. In Keibel and Mall, Manual of Human Embryology. J. B. Lippineott Co., Philadelphia, 2: 534570.

1913 Anatomie des Herzens. In Bardeleben, Handbuch der Anatomie des Menschen. Gustav Fischer, Jena, 3: 1-292.

Tawara, S. 1906 Das Reizleitungssystem des Säugetierherzens. Gustav Fischer, Jena, 194 pp.

1906 Über die sogenannten abnormen Sehnenfäden des Herzens. Ziegler's Beitr., Jena, 39: 563-584.

Todaro, F. 1877 Sulla struttura muscolara dei ventricoli del cuore umano. Atti d. R. Accad. d. Lincei, Trans., Series 3, 1: 30-31.

Trincr, G. 1907 Cellule cromaffini e "Mastzellen", nella regione cardiaca nei mammiferi. Mem. Accad. Sci. Inst., Bologna, Series 4, 6: 21-26.

Warts, E. W. 1947 The development of the specialized conducting tissue of the human heart. J. Anat., 81: 107-109.

Waterston, D. 1918 The development of the heart in man. Trans. Roy. Soc. Edimburgh, Pt. II, 52: $257-302$.

WAтzKa, M. 1930 Ueber die Verbindungen inkretorischer und neurogener Organe. Verhandl. d. anat. Gesellsch., Amsterdam, 39: 185-190.

WENCKEBACH, K. F. 1907 Beiträge zur Kenntniss der menschlichen Herztätigkeit. Arehiv f. Anat. u. Physiol. (Physiol. Abtlg.), Part II, pp. 1-24.

WiEsel, J., AND A. BIEDL 1902 Ueber die functionelle Bedeutung der Nebenorgane des Sympathicus und der chromoffinen Zellgruppen. Centralbl. Physiol., 16: 612-613.

WolfF, L., J. Parkinson AND P. D. White 1930 Bundle-branch block with short $\mathrm{P}-\mathrm{R}$ interval in healthy young people prone to paroxysmal tachyeardia. Am. Heart J., 5: 685-704.

Woroвiew, W. 1928 Plica nervina atrii sinistri. Zeitschr. f. Anat. u. Entwg., $86: 508-516$.

Wright, R. R., B. J. Anson and H. C. Cleveland 1948 The vestigial valves and the interatrial foramen of the adult human heart. Anat. Rec., 100: 331-356. 
WrISBERG, H. A. 1793 Observationes anatomicae-physiologicae de nervis aterias venasque comitantibus. Seript. neurol. minores selecti, 3: 24-47.

YATER, W. M. 1929 Variations and anomalies of the venous valves of the right. atrium of the human leart. Areh. Path., $7: 418-441$.

ZuCKERKANDL, E. 1881 Über die Anastomosen der Venae pulmonales mit den Bronchial Venen dem mediastinalen Venennetze. Sitzungsber. d. Kaiserlichen Akad. d. Wiss. (Wien). Math.-Naturwiss. Klasse, 84: 110-152. 